\title{
A Role for Eosinophils in Adaptive Humoral Immunity
}

\author{
Robert S. Speirs ${ }^{1}$, Elizabeth E. Speirs ${ }^{1}$ and Nicholas M. Ponzio ${ }^{*}, 2$ \\ ${ }^{1}$ Department of Anatomy (Retired), SUNY Downstate Medical Center Brooklyn, NY, USA \\ ${ }^{2}$ Department of Pathology and Laboratory Medicine, UMDNJ - New Jersey Medical School, Newark, NJ, USA
}

\begin{abstract}
This review describes eosinophils in the context of their conspicuous presence as part of the memory (i.e., anamnestic) immune response to antigen. We propose a role for eosinophils, along with Antigen Presenting Cells (APC), in the initiation of humoral immune responses to protein antigens by memory T Helper-2 (TH2) cells and memory B lymphocytes. Eosinophils have long been known as a component of the inflammatory response induced during prolonged or repeated exposure to diverse antigens. However, their precise contribution to secondary antibody responses remains to be fully clarified. These morphologically unique granulocytes possess a wide assortment of preformed cytokines, interleukins, chemokines and RNAses (collectively known as eokines), which can be rapidly released during an inflammatory response to foreign proteins. Their accumulation and release of diverse eokines during the inflammation that accompanies an anamnestic response suggests an immunoregulatory function for eosinophils. Based on published results, we propose that preformed eokines attract dendritic cells and other APC to the inflammatory site and contribute to their maturation and activation. In addition, eosinophil RNAses and other enzymes catabolize cellular products (e.g., dsRNA complexes) released by antigen-activated memory TH2 cells undergoing apoptosis. As shown for other antigeninduced responses, B memory cells could bind components of RNA and other molecules present in the inflammatory exudate via their cell surface Toll Like Receptors (TLR), contributing to activation, clonal expansion, and differentiation into antibody-producing plasma cells. Overall, we present a unifying hypothesis to account for the presence and immunomodulatory role of eosinophils in the humoral immune response.
\end{abstract}

Keywords: Eosinophil, humoral immunity, immunological memory, $\mathrm{T}$ memory cells, B memory cells, antibody response, cytokine, immunomodulation, cell-cell interactions.

\section{INTRODUCTION}

The presence of antigens in immunologically competent animals initiates an elaborate, well integrated series of reactions and interactions involving multitudes of cells that originate primarily in the myeloid and lymphoid tissues, and migrate into the blood and into the induced inflammatory area. The cellular responses to antigen or its epitopes (antigenic components) culminate in the induction of cellmediated immunity, primary and/or anamnestic humoral responses, autoimmunity and/or tolerance. These response mechanisms all involve the reaction of specific cellular components with the foreign agent, with each other and/or with the chemokines, growth factors and cytokines released by activated cells [1-7]. It also involves transfer of specific information from one cell to another during the induction of humoral immunity.

The types of cells participating in the induced inflammation have been extensively investigated and their role in the humoral aspects of adaptive immunity described. However, there has been one notable exception - the eosinophil. The attention given to the beneficial or adverse reactions generated by eosinophils and their secreted products in asthma, other allergic reactions, and parasitic

*Address correspondence to this author at the Department of Pathology and Laboratory Medicine, UMDNJ, New Jersey Medical School, 185 South Orange Avenue, Newark, NJ 07103, USA; Tel: (973) 972-5238; Fax: (973) 972-7293; E-mail: ponzio@umdnj.edu infestations is well documented. We acknowledge the large body of literature on the role of eosinophils in these scenarios, which have been described in several excellent reviews on these topics [8-13]. By comparison, there have been relatively few studies on the involvement of eosinophils in humoral immune responses. This review chronicles the contribution of eosinophils to various stages of humoral adaptive immunity, and re-interprets some of the existing data in these areas in light of newer discoveries about cellular interactions involved in the antibody response to protein antigens. We also suggest a regulatory role for eosinophils in these reactions, and in the possible transfer of information from memory $\mathrm{TH} 2$ cells to memory B cells.

The cellular components migrating to the site of inflammation include two types of granulocytes -neutrophils and eosinophils. Both are "end cells" with segmented nuclei containing compact nuclear material, primarily heterochromatin, without the capacity for renewed DNA synthesis. Preformed enzymes and related proteins are stored in distinct cytoplasmic structures, and can be rapidly released as the cells leave the blood vessels and enter the inflammatory area. Both cell types have a very limited life span and are incapable of replication.

$\mathrm{T}$ and $\mathrm{B}$ lymphocytes, macrophages, and dendritic cells, each containing nuclear material capable of increasing their euchromatin, and cytoplasmic structures, also migrate into the inflammatory area. Although these cells carry a minimum of preformed enzymes, they have the capacity to respond by developing DNA-dependent RNA synthesis and 
new protein formation. They react somewhat more slowly than the granulocytes, but tend to persist much longer in the inflammatory area and are ultimately transported into the draining lymphatics and into regional lymph nodes. They may also demonstrate DNA replication followed by cell division in associated granulomatous areas and in regional lymph nodes. The specific membrane receptors characteristic of each cell type and their capacity to initiate signal transduction event(s) within the cell have a significant role in the initiation of immunity.

\section{GENERAL INFORMATION ABOUT EOSINOPHILS}

Eosinophils are a component of the mobile cell population normally resident in the connective tissue fluids associated with the respiratory and gastrointestinal tracts and in bone marrow, spleen and lymph nodes. They are a component of the inflammatory response and their numbers increase greatly during prolonged or repeated exposure to parasitic organisms or antigenic material (see Figs. 1-3) [6, $14,15]$. In contrast, repeated injections of carbon, isologous proteins or non-cross reacting antigens do not initiate an augmented and prolonged eosinophil response [16, 17].

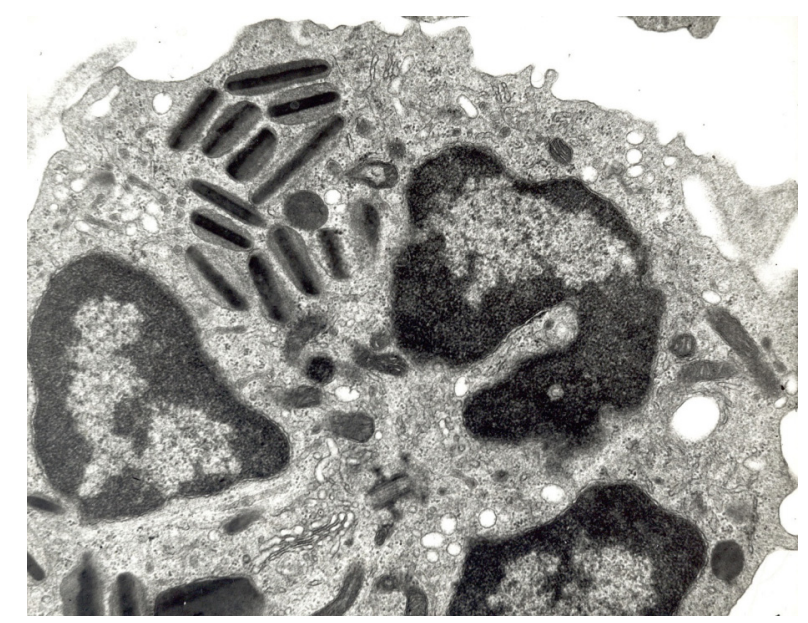

Fig. (1). Electron micrograph of a mature mouse eosinophil.

The mature eosinophil has a donut shaped nucleus, stretched into a thin shape and often folded. Dense heterochromatin is compressed along the inner nuclear membrane with a relatively small amount of euchromatin in the center, and an occasional nuclear pore can be seen. Large cytoplasmic granules with a dense core surrounded by less dense granular material are a conspicuous cytoplasmic component. Mitochondria are also present along with a prominent golgi apparatus and a nearby single centrosome. Ribosomes are scattered throughout the cytoplasm but not directly associated with the endoplasmic reticulum (Fig. 1). Mature eosinophils are not capable of cell division and have minimal capacity for initiating new protein synthesis. However, they do possess a wide assortment of preformed cytokines, interleukins, chemokines and RNAses, which can be rapidly released during an inflammatory response.

Eosinophils are also conspicuously present in the secondary (anamnestic) response to foreign proteins. This is demonstrated in Fig. (2) in which adult mice were first primed subcutaneously with tetanus toxoid plus pertussis vaccine and reinjected i.p. 4, 8 and 16 weeks later. The column on the left represents controls primed with tetanus toxoid and injected i.p. with diphtheria toxoid. The remaining columns are mice challenged with tetanus toxoid at 4,8 and 16 weeks after priming. Each point represents an average of 5 mice plus or minus the standard error of the mean.

When re-injected with the priming antigen, the eosinophil response (middle row) consistently demonstrated an elevated response, peaking on day 3 , in comparison to the neutrophil response (top row). The mononuclear cells (macrophages, lymphocytes and dendritic cells) did not show distinct differences between animals injected with diphtheria toxoid vs tetanus toxoid [5].

High titers of humoral antitoxin also occur following reinjection of tetanus toxoid in mice (Fig. 3).

Humoral antitoxin production involves the reaction of memory cells with the antigen, leading to formation of plasma cells that synthesize and secrete the antitoxin. It is of interest to note that the eosinophil response precedes the detection of serum antitoxin (Fig. 3). In other experiments (not shown), mice passively immunized by a prior injection of homologous or isologous antitoxin did not demonstrate a secondary type eosinophil response at the site of injection. Antigen-antibody complexes are therefore not responsible for the prolonged eosinophil responses at the site of injection [18].

Eosinophils have an array of receptors that are different from other leukocytes present in the inflammatory exudate [19]. They also have an assortment of preformed interleukins, other cytokines and chemokines stored in their granules $[20,21]$ ready for quick release into the inflammatory milieu. These attributes provide eosinophils with a unique capacity for rapid participation in inflammatory and immune reactions to an antigen. Eosinophils are poorly phagocytic and do not actively engulf particulate antigens. They may, however, engulf soluble antigen or antigen/antibody complexes, and eosinophils can act as antigen-presenting cells to $\mathrm{T}$ lymphocytes [22-25]. Mature eosinophils are "end cells" unable to undergo further mitosis [26]. They are a minor cellular component of most inflammatory reactions. When viewed against a background of proteinaceous material they are somewhat difficult to detect in hemotoxylin and eosin sections and are frequently overlooked, especially in the mouse. However under phase or electron microscopy, or treatment with special stains their large acidophilic granules make them very conspicuous. Toxic materials, stress, or corticosteroids drastically lower the number of circulating eosinophils available for participating in the inflammatory response $[14,27]$. Accordingly, removal of endogenous corticosteroids in adrenalectomized mice consistently produces higher eosinophil counts in response to challenging injections with a variety of different antigens [16, 28].

With their segmented nucleus, condensed chromatin, and little or no rough endoplasmic reticulum (RER), mature eosinophils exhibit restricted synthesis and secretion of new protein molecules. However, production and release of mRNA can be induced in peritoneal eosinophils [29]. Their cytoplasm is packed with distinct membrane-bound acidophilic granules containing a variety of preformed enzymes which can be released through piecemeal 


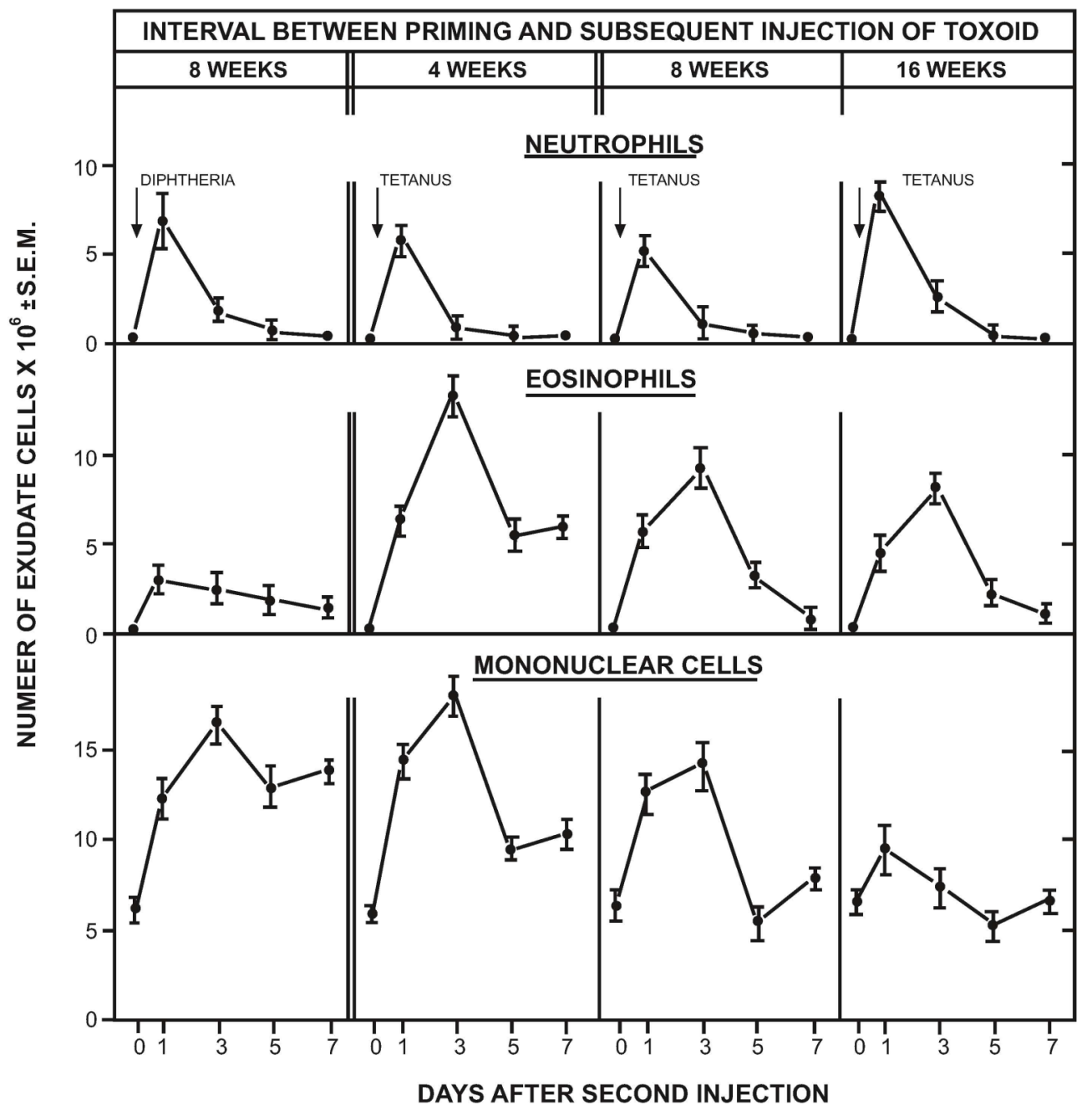

Fig. (2). Inflammatory response at the site of injection - the peritoneal cavity.

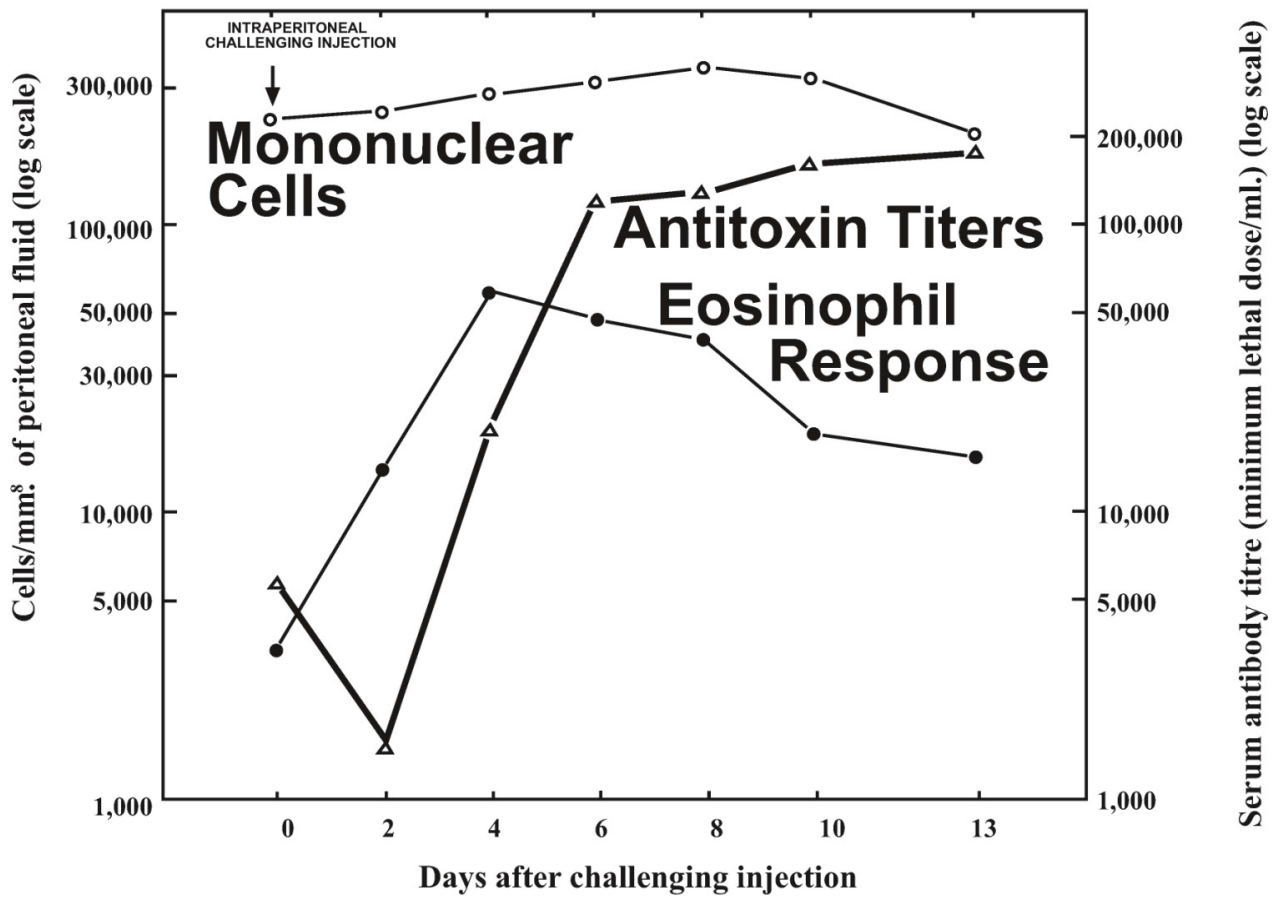

Fig. (3). Secondary eosinophil and antitoxin responses after a challenge injection of tetanus antigen to tetanus toxoid-primed mice. 
degranulation, exocytosis and/or cytolysis [30]. Eosinophils also possess a diverse array of cytoplasmic chemokines and cytokines, collectively called eokines (Table $\mathbf{1}$ ).

Table 1. This is a Partial List of Eosinophil Mediators from References Cited in the Text. A More Comprehensive List Can Be Found at URL www.copewithcyto kines.de/

\begin{tabular}{|c|c|c|}
\hline \multicolumn{3}{|c|}{ Mediators Produced by Eosinophils } \\
\hline Interleukins & Chemokines & Other \\
\hline \hline IL-2 & Eotaxins & RNAse-2 (Eosinophil-derived Neurotoxin) \\
IL-3 & RANTES & RNAse-3 (Eosinophil Cationic Protein) \\
IL-4 & MCP-3 & Eosinohil Peroxidase \\
IL-5 & MCP-4 & Major Basic Protein \\
IL-6 & MIP-1 $\alpha$ & \\
IL-10 & & \\
IL-12 & & \\
IL-13 & & \\
IL-16 & & \\
IFN- $\gamma$ & & \\
TNF- $\alpha$ & & \\
\hline
\end{tabular}

Abbreviations: IL-Interleukin; IFN-Interferon; TNF-Tumor Necrosis Factor; RANTESRegulated upon Activation, Normal T cell Expresses and Secreted; MCP-Monocyte Chemoattractant Protein; MIP-Macrophage Inflammatory Protein; GM-CSFGranulocyte Macrophage Colony Stimulating Factor.

These eokines include Interleukins (IL-2, IL-3, IL-4, IL5, IL-6, IL-13) growth factors (GM-CSF), and many other polypeptides such as adhesion molecules, lipolytic enzymes, cytotoxic materials (e.g., major basic protein-MBP), eosinophil cationic protein (RNase-3), eosinophil-derived neurotoxin (RNase-2), and eosinophil peroxidase (EPO) [19, 31-35].

The recruitment of eosinophils into the inflammatory area involves a series of interactions between a multitude of chemoattractants and cell adherence mechanisms. These include ecalectin/galectin-9, RANTES, and the eotaxins released by memory $\mathrm{T}$ cells and nearby associated cells, which collectively induce eosinophil chemotaxis, aggregate formation, degradation, apoptosis and release of other cellular stimulants such as IL-4 [36-41].

RNAse-3 (also known as Eosinophil Cationic Protein; ECP), and RNase-2 (also known as Eosinophil-Derived Neurotoxin; EDN) are members of the RNAse superfamily found in higher animals. They are distinctive cationic proteins present in eosinophil granules, and they can be released into the inflammatory exudate during re-exposure to a protein antigen. RNase-3 contains an abundance of arginine molecules which attach to plasma membranes, destabilizing the lipid bilayers and increasing their permeability, presumably by forming ion channels [42] and/or by membrane depolarization. RNase-3 also acts to inhibit further growth of cells without being catalytic. RNase-2 is composed of fewer arginine molecules and is associated with higher RNAse activity but less cell toxicity. Some arginine-rich peptides can act as cell-penetrating peptides (CPP), capable of passing through plasma membranes while carrying protein and nucleic acid cargo [43]. Since RNase-3 has been shown to increase plasma membrane permeability to nutrients it would be of interest to determine if the RNAse can also modify plasma membranes, facilitating entry of mRNA and other materials into target cells.

The accumulation of eosinophils and the release of their diverse eokines during the inflammatory process suggests that they must have an immunoregulatory function $[18,23$, $33,44-47]$. The eosinophil has been referred to as a "pleiotropic multifunctional leukocyte" acting as a modulator of innate and adaptive immunity [48]. Cellular immunity involves memory of an earlier exposure to antigen, leading to an elevated eosinophil response which can occur in the absence of humoral immunity [49]. Eosinophil numbers increase significantly during allergic phenomena $[50,51]$, in parasitic $[52,53]$ and viral infestation $[54,55]$, in chronic inflammation [56, 57] and in some cancers [58]. Eosinophils possess antibacterial properties [59], and can also kill nematode larvae, either alone or in conjunction with other immune components such as antibody or complement $[60,61]$.

Eosinophils and their enzymes have also been shown to influence the proliferation of activated $\mathrm{T}$ and $\mathrm{B}$ memory cells [62] but have little or no effect on naive T and B cells. They also enhance mast cell activation in allergic inflammation $[63,64]$. While eosinophils play a very prominent regulatory role in inflammation and in cell mediated immunity their role in adaptive humoral immunity is much less clear. It has been demonstrated that activated CD4 T memory cells are essential for both the secondary eosinophil responses and for the humoral $\mathrm{IgG}$ antibody responses to most protein antigens. The eosinophil response precedes the development of cell mediated immunity and it seems likely that some aspects of the response could also contribute to the initiation of adaptive humoral responses.

Based on their presence at sites of antigen-induced inflammation, and their unique functional properties, a role for eosinophils in humoral immune responses can be easily envisioned as presented in Text Box 1.

\section{Box 1. Proposed Roles for Eosinophils in the Humoral Immune Response}

Eosinophils can influence humoral immune responses in multiple ways by virtue of their unique functional characteristics, such as:

- Recruitment to inflammatory sites in response to chemoattractants and cell adherence mechanisms.

- Release of preformed cytokines, chemokines and other mediators, which fuel the inflammatory response.

- Ability to ingest soluble antigen or antigen-antibody complexes, upregulate MHC Class II and costimulatory (CD80/86) molecules, and present antigenic peptides to $\mathrm{T}$ cells.

- Release of RNAse-3 (Eosinophil Cationic Protein), which attracts Dendritic Cells (DC) to inflammatory sites and promotes DC maturation and activation, thereby facilitating antigen presentation to $\mathrm{TH}$ cells.

- Release of RNAse-2 (Eosinophil-Derived Neurotoxin), which reacts with dsRNA released from antigen-activated TH cells undergoing apoptosis.

- Ability to influence clonal expansion and differentiation of TH and B memory cells via secretion of preformed cytokines (IL-2, IL-4, IL-5, and IL-6), contributing to isotype switching and development of antibody-producing plasma cells. 


\section{PRIMARY VS ANAMNESTIC RESPONSE}

The characteristic feature of the vertebrate adaptive immune response is the ability to recall previous exposure to a foreign agent and to respond with an augmented inflammatory response and a prolonged, more efficient and highly specific humoral antibody response. Concepts of adaptive immunity have evolved from the simple to the very complex regarding the types of cells involved, the cell-tocell reactions, and the release and response of the multiplicity of chemokines, cytokines and mitotic agents in the cellular milieu $[44,65,66]$.

A primary i.p. injection of a non-toxic antigen, such as tetanus or diphtheria toxoid, produced little fluctuation in total cells or in the number of eosinophils in the blood or peritoneal cavity when measured daily for 10 days. However, while a second i.p. injection of the same antigen produced only moderate changes in cell numbers in the blood, major increases in the number of total cells and in the number of eosinophils were recorded at the site of injection $[3,5,15]$. This local prolonged eosinophilia was not obtained in passively immunized animals [67], in animals reinjected with isologous proteins [17], or when multiple injections of non-related antigens were administered. These experiments suggest that during the secondary (anamnestic) response, the local eosinophil response represents a stage of cell mediated immunity, and possibly an early stage of humoral immunity.

$\mathrm{CD}^{+} \mathrm{T}$ cells are central regulators of both humoral and cell-mediated immune responses. The initiation of memory formation in naive $\mathrm{T}$ cells involves a number of sequential steps [68-72]. During the primary response, Antigen Presenting Cells (APC; dendritic cells, macrophages, B cells, eosinophils) capture, process and express antigenic peptides in the context of surface molecules encoded by genes in the Major Histocompatibility Complex (MHC). Then, clonal selection of naïve $\mathrm{T}$ lymphocytes with receptors (TCR) capable of complexing with the antigenic peptides occurs. During this primary response, signaling occurs between antigen-specific $\mathrm{T}$ cells and APC, which is mediated by cytokines and costimulatory molecules. The types of cytokines and signaling that occurs during these APC-T cell interactions determine the nature of the $\mathrm{T}$ effector and $\mathrm{T}$ memory cells that are produced, which in turn influence the magnitude, longevity and quality of the subsequent anamnestic response to that antigen [73].

Humoral immunity is characterized by the generation of B memory cells that can rapidly generate specific antibodysecreting plasma cells upon re-exposure to antigen. A critical difference between B cells and T cells is how each "sees" the antigen. B cells recognize the cognate antigen in its native form by their membrane bound-immunoglobulin receptor, also known as the B Cell Receptor (BCR) for antigen. In contrast, $\mathrm{T}$ cells recognize the cognate antigen in a processed form, as a peptide fragment presented by MHC molecules on APC. Both $\mathrm{T}$ and $\mathrm{B}$ memory cells can persist for long periods, migrating and recirculating throughout the lymphatic and other tissues of the body. They have the capacity to rapidly respond upon re-exposure to the same antigen or its peptide. During this anamnestic response, activated $\mathrm{B}$ cells are capable of triggering $\mathrm{T}$ cell activation, and production of cytokines that drive Ig isotype switching and production of high-affinity antibodies from B cells [74].

Complexing of antigenic epitopes with cell receptors stimulates clonal expansion of antigen-specific $\mathrm{T}$ and $\mathrm{B}$ cells, yielding daughter cells that express membrane receptors identical to those on the parent cells [74-78]. Although all the antigen receptors on each individual $\mathrm{T}$ or $\mathrm{B}$ cell clone are identical, the specificity of the receptors varies greatly from one clone to another. This clone-to-clone heterogeneity facilitates the binding of many different antigenic epitopes. Since each antigen may be composed of many different epitopes, a corresponding range of $\mathrm{T}$ and $\mathrm{B}$ cells is required, each with receptors compatible with one of the specific epitopes. The B cell receptors react to the shape of the protein antigen while the $\mathrm{T}$ cell receptors react to the antigen peptides. Recent experiments have suggested that, following antigenic stimulation, the $\mathrm{T}$ cell may undergo asymmetric cell division, resulting in two types of progeny $\mathrm{T}$ effector cells and T memory cells [79].

Re-exposure to the same antigen or antigenic epitope activates the CD4 T memory cells (TH1 and TH2), triggering release of a variety of chemokines, cytokines and growth factors. The cytokines released from activated CD4 memory cells (IL-2, IL-4, IL-5, IL-7, IL-15, IL-21) are important in the regulation of hematopoiesis and immune responses, and can influence both $\mathrm{T}$ and $\mathrm{B}$ cell proliferation and development $[80,81]$. One of the secreted cytokines is IL-5, which stimulates eosinopoiesis, differentiation, and release of mature eosinophils from the bone marrow to participate in the induced inflammatory process [6, 82-85]. IL-9 and RANTES, also released from activated CD4 T memory cells, greatly augment the eosinophil response induced by IL-5 [86]. Stimulation of fibroblasts with IL-4 and TNF- $\alpha$ caused a 10 - to 20 -fold increase in the release of three different eotaxins which are also eosinophil chemoattractants.

Use of Actinomycin D (Act-D), a polypeptide antibiotic that blocks DNA-dependent RNA synthesis [87, 88], revealed a differential effect on cells involved in primary $v s$ secondary responses to tetanus toxoid. When administered during priming, Act-D prevented formation of memory cells required to produce the characteristically high levels of $\mathrm{IgG}$ antibody measured upon secondary antigen injection [89-93]. Once memory cells were formed, however, treatment with Act-D did not prevent IgG antibody formation [44, 87, 89]. In contrast, there was no effect of Act-D on the eosinophil response to antigen challenge. The inhibitory action of Act-D on primary immunization and its failure to affect the anamnestic response demonstrates a distinct difference in the role of DNA-dependent RNA synthesis in the two stages of immunity. Moreover, the presence of eosinophils at the site of antigen challenge despite treatment with Act-D suggests that they may play a role in the anamnestic reactions leading to the initiation of antibody formation.

The use of tritiated $\left({ }^{3} \mathrm{H}\right)$ tetanus antigen in mice highly sensitized to tetanus toxoid revealed the fate of antigen and the induction of ${ }^{3} \mathrm{H}$-labeled mononuclear cells that became swollen and vesiculated, forming cellular aggregates with eosinophils, lymphocytes and macrophages [3]. Labeled 
mononuclear cells were found in the inflammatory exudate of animals challenged as long as 270 days after tetanus toxoid priming. In separate ex vivo experiments, these swollen vesiculated cells were found to release chemoattractants for eosinophils, which often formed a "rosette" around the swollen cell (see Figs. 4, 5) [3, 94, 95].

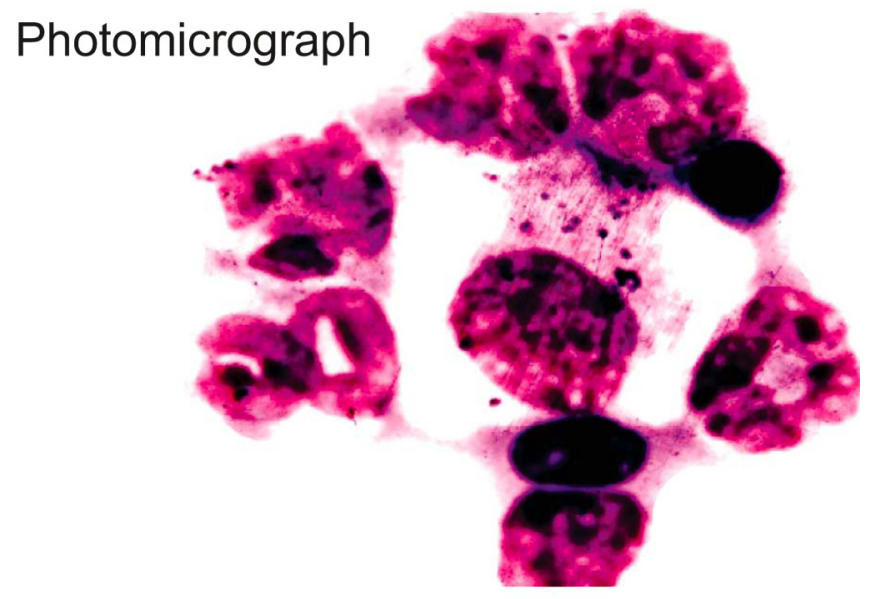

Fig. (4). Chemotactic response of eosinophils to swollen injured cells. This micrograph shows a rosette of 5 eosinophils and two small lymphocytes around a vesiculated swollen cell. Such rosettes occur only in animals primed and challenged with the same antigen. Eosinophils observed in ex vivo cultures were chemotactically attracted to swollen cells taken from the inflammatory exudates, but not to the antigen itself [3].

Eosinophils that directly contact both $\mathrm{T}$ and $\mathrm{B}$ memory cells have the potential to release eokines, which could markedly alter both cell types. In antigen-induced granulomas, eosinophils subsequently appear in the vicinity of dividing $\mathrm{B}$ memory cells as they transform into plasma cells $[6,83,93]$. Eokines IL-2, IL-5 and IL-6 are known to have an effect on B cell proliferation and on IgM production [96-98]. IL-4 and IL-5 eokines are involved in the isotype switch that occurs in antibody-producing B cells [99].

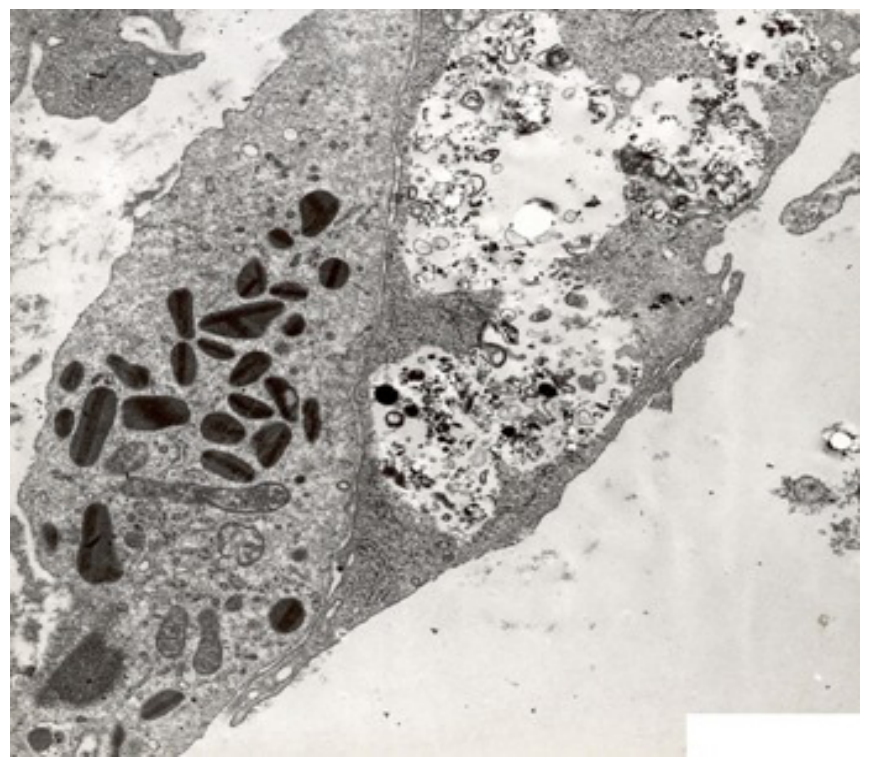

Fig. (5). Electron micrograph illustrating the close attachment of an eosinophil (left) to a swollen ${ }^{3} \mathrm{H}$-antigen containing cell (right) following re-exposure to specific antigen.
IL-2, a component of eosinophil granules [100], is known to bind to IL-2 receptors on T cells, inducing apoptosis [101103]. Thus eosinophils could have a role in the breakdown of CD4 $\mathrm{T}$ memory cells following re-exposure to the antigen epitope. Tetanus-primed control animals injected with noncross reacting diphtheria toxoid antigen did not demonstrate such responses.

Another eokine, eosinophil cationic protein (RNase-3), has been shown to block immunoglobulin transcription and proliferation of existing pre-plasma cells without affecting their viability $[104,105]$. IL-5, in combination with IL-2, has been reported to activate Blimp-1, a transcriptional repressor which is a B cell maturation protein required for the conversion of B cells into plasma cells [106-110]. These activities emphasize the potential significance of eosinophils and their eokines in the antibody forming process.

Adaptive immune responses are so complicated and involved that reductionist approaches are generally used to define each interacting component [111]. In vitro experiments to clarify the steps leading to humoral adaptive immunity have also been reported [71, 112-114]. However, the complete process involving primary and secondary responses has yet to be fully defined. Among the complicating factors are: 1) The showers of chemokines, cytokines and/or growth factors contributed progressively by each cell type as they take part in the inflammatory process; 2) cell-to-cell and cytokine/chemokine-to-cell reactions; 3 ) phagocytosis, apoptosis and granuloma formation around antigen deposits; 4) clonal expansion and differentiation of $\mathrm{T}$ and B memory cells, each with receptors specific to an antigenic epitope; 5) activation of B memory cells in the presence of activated CD4 T memory cells when each of their receptors complex with an epitope; 6) adoptive transfer of information from the activated $\mathrm{T}$ memory cell to the activated B memory cell; 7) conversion of polyribosomes to ribosomes capable of combining with newly released mRNA; 8) reformation of polyribosomes containing mRNA coding for heavy and light chains of the immunoglobulin molecule; 9) isotype switching from IgM to $\operatorname{IgG}$, IgE or IgA by differentiated plasma cells.

\section{RELATION OF DENDRITIC CELLS TO EOSINO- PHILS}

The dendritic cell (DC) is essential for initiating both primary and anamnestic immune responses [69, 115-119]. Dendritic cells are phagocytic with a unique capacity for antigen presentation and stimulation of naïve, memory and effector $\mathrm{T}$ and $\mathrm{B}$ cells. They originate in the bone marrow, and migrate via the blood and lymphatic vessels into peripheral lymphoid tissues. By their Antigen Presenting Cell (APC) function, DCs stimulate clonal expansion and differentiation of antigen-specific $T$ cells that recognize the antigen fragment or epitope $[70,120]$. They also produce IL15 , which enhances germinal center $\mathrm{B}$ cell proliferation [121].

DCs are attracted into the inflammatory exudate following release of RNAse-2 by eosinophils, facilitating their maturation and activation $[122,123]$. They also play a role in the initiation of antibody synthesis by direct interaction with B cells [124-128]. In addition IL-3, an 
eokine secreted by eosinophils, induces a shift in cell responses to a Th2 cytokine pattern [129].

Several subsets of dendritic cells (DC) carrying different membrane receptors reside in different locations in spleen and lymph nodes and have different functions [130-132]. One DC subset engulfs and internalizes dead cells and can lead to transfer of processed antigen [133-135]. Another subset expresses Toll-like Receptor-3 (TLR3) molecules, which can complex with dsRNA, leading to DC activation, the production of IFN- $\alpha$, and facilitation of $\mathrm{T}$ cell proliferation [136]. A third subset, plasmacytoid DC (pDC), exhibits plasma cell-like morphology [137]. All subsets appear to take up and process antigen, and to present peptide fragments in the context of MHC molecules to T cells.

Thus, the attraction of dendritic cells into the inflammatory exudate suggests that by release of eokines, eosinophils could serve to regulate aspects of the humoral immune response.

\section{INFLAMMATORY EXUDATE}

The inflammatory exudate, with its burden of dendritic cells, eosinophils, T and B memory cells, as well as cellular debris and a broad assortment of enzymes, flows into the afferent lymphatics and into the regional lymph node(s) [4, 17, 138-140]. Subsequent reactions lead to the transformation of B memory cells into plasma cells both locally in the granulomatous tissue and in the regional lymph nodes [45, $83,141,142]$. Some of the $\mathrm{T}$ and $\mathrm{B}$ memory cells pass via the thoracic duct to the blood and to lymphatic and myeloid tissues. They eventually become a component of the mobile (i.e., recirculating) lymphocyte population [65, 143-147].

\section{ROLE OF THE THYMUS}

The importance of the thymus in lymphopoiesis and in certain immunological responses has been well documented [148, 149]. In Thymectomized, Irradiated and hematopoietically Reconstituted (TIR) mice the mononuclear and eosinophil cell responses to a challenging injection of tetanus toxoid were drastically reduced [150]. The responses to carbon, a non-antigenic stimulus, were not altered. TIR mice have a normal level of bone marrow eosinophils which suggests that while thymectomy does not reduce the capacity for eosinophil formation, it does generate a deficiency in the cellular mechanisms involving eosinophil responses to antigen. Subcutaneous implants of intact thymus restored the capacity of these mice to demonstrate normal mononuclear and eosinophil responses to antigen.

In summary, a shortage of $\mathrm{T}$ cells capable of reacting to antigen and releasing cytokines is responsible for the failure of the secondary eosinophil response in thymectomized, irradiated and reconstituted mice.

\section{EFFECT OF CORTISONE}

Stress, which involves release of cortisol by the adrenal cortex, greatly influences the immune response [151]. Cortisone acetate, which inhibits the eosinophil response, also prevents antibody formation in mice [27, 152-155]. While it does not appear to act directly on pre-existing eosinophils, it does facilitate a marked reduction in eosinophil release from the bone marrow. This was demonstrated in mice by intraperitoneal implantation of cortisone acetate pellets into an inflammatory exudate containing many eosinophils [14]. A rapid decrease was measured in the blood eosinophils while the number of eosinophils in the peritoneal exudate declined slowly. This suggests an indirect effect of cortisone acetate on mechanisms involved in eosinophil formation and release rather than a direct effect on eosinophils in the inflammatory area.

\section{EFFECT OF X- IRRADIATION}

Experiments involving whole body X-irradiation, administered before and after antigen exposure, demonstrate that the radiation-sensitive stage of antibody formation coincides with the stage when irradiation markedly reduces the number of eosinophils responding to antigen injection $[156,157]$. When sufficient numbers of preformed eosinophils were present at the time of antigen injection, the anamnestic antibody formation was not affected by irradiation, suggesting a possible role for eosinophils in the development of humoral immunity.

Separate experiments further demonstrated that cell mediated responses to tetanus toxoid were more radioresistant than humoral antibody responses [156-160]. While immune spleen cells exposed to $100 \mathrm{r}$ or 400r irradiation in vitro were able to induce an eosinophil response after adoptive transfer, the humoral response was abolished. In contrast, after exposure to 500r irradiation, both responses were abolished. This demonstrates distinct differences in radiation-sensitivity between cells capable of inducing a secondary eosinophil response and cells involved in the production of IgG antibody (antitoxin).

\section{TREATMENT OF PRIMED MICE WITH ANTI-LYM- PHOCYTE SERUM}

Anti-lymphocyte serum inhibits the eosinophil response, as well as new antibody formation, after a challenging antigen injection to previously immunized mice. However, when CD4 $\mathrm{T}$ memory cells were adoptively transferred following anti-lymphocyte serum treatment of such antigenprimed mice, both mononuclear and eosinophil cell responses were greatly augmented and $\mathrm{IgG}$ antibody formation occurred after antigen challenge [67, 161-163].

\section{PASSIVELY IMMUNIZED MICE}

An intraperitoneal injection of tetanus toxoid into nonimmunized mice induces a transient eosinophil response, peaking at 24 hours. By comparison, animals previously primed by a subcutaneous injection of the tetanus toxoid and challenged intraperitoneally have higher numbers of eosinophils at 24 hours, which continue to increase until reaching a peak at 3 - 4 days (Fig. 3). They are still present at days 5 and 7, and are also found in the granulomas where B memory cells are transforming into plasma cells. While injections of either heterologous or isologous anti-tetanus antibody prior to challenge did not suppress the transient eosinophil response they did prevent any prolonged accumulation of eosinophils [15, 67]. This suggests that the transient phase is due to non-specific permeability of the blood vessels while the prolonged eosinophil response requires specific stimuli, such as the chemoattractants released by activated CD4 $\mathrm{T}$ memory cells. 
A specific antibody injection prior to or simultaneously with a priming dose of antigen suppresses humoral immunity in mice $[164,165]$. One explanation for this phenomenon is masking of antigenic epitopes, thereby preventing antigenspecific lymphocytes from recognizing and responding to the antigen [165]. For T cells, such epitope masking would also interfere with effective T cell-APC interaction, and prevent the release of chemokines and cytokines that augment local eosinophil responses, and which lead to B cell transformation and antibody formation.

\section{ADOPTIVE TRANSFER OF MEMORY CELLS}

A system of adoptive transfer of lymphoid cells from immunized mice into immunocompromised mice was used in order to establish the specific role of various cells in the immune process (Fig. 6). This involved the use of recipient TIR mice that were Thymectomized, lethally Irradiated (1100r) and Reconstituted with bone marrow or fetal liver cells $[45,65,143,145,148]$. Anamnestic eosinophil and antibody responses to tetanus toxoid were obtained in these mice only when viable lymphoid cells from immunized mice were injected intravenously after irradiation. There was a delay in both the eosinophil response and the $\mathrm{IgG}$ antibody production, presumably due to the time required for the transferred hematopoietic cells to divide and form the colonies that produce mature blood cells. Eosinophil colonies were observed in both the spleen and bone marrow prior to IgG antibody (antitoxin) production [148]. Neither serum nor cell-free lymph from normal mice was effective in transferring the immunity.

Adoptive transfer of primed lymphocytes also established colonies in the bone marrow and spleen, which furnished the memory cells enabling the irradiated mice to respond to a challenging injection of antigen (Fig. 6).

The capacity to induce an antitoxin response first occurred in the regional lymph node (LN) 10 days after priming. At this time the other LNs and the spleen did not have this capacity even when the number of transferred cells was greatly increased. By day 17 adoptive transfer of responses occurred from cells in the spleen and in some LNs. By day 30, cells from all LNs transferred the capacity to produce high antitoxin responses. Thus, between days 10 and 30 the capacity to induce antitoxin production spread from the regional LN to all peripheral lymphoid tissues. The memory cells involved in the eosinophil response to challenge began to appear in spleen and LNs between days 3 and 6 , reaching a peak by day 10 . Ten days after priming, the spleen contained memory cells capable of adoptively transferring a high eosinophil response to challenge but were unable to induce antitoxin formation. By days 17 and 30, primed spleen cells were able to transfer both the eosinophil and antitoxin responses to challenge. This difference in the rate of appearance of memory cells facilitated the individual study of each population [144].

This experiment indicates that when spleen cells were transferred 10 days after priming, a secondary eosinophil response to challenge was obtained but no $\mathrm{IgG}$ antibody was produced. However, when spleen cells were transferred 30 days after priming, high IgG antibody responses and high eosinophil responses were obtained. This suggests that at 10 days only CD4 T memory cells are present in the spleen but at 30 days B memory cells are also present (see Fig. 6) [144].

In one experiment, irradiated mice receiving primed spleen cells but no bone marrow or fetal liver cells, had increased IgG antibody titers. This suggests that mature radiation-resistant eosinophils present at the time of adoptive transfer contributed to the challenging response. In irradiated animals new eosinopoiesis begins in the bone marrow by day 18. In all cases the transfer of cells obtained from bone marrow, thymus, or spleen from primed donors provided higher eosinophil counts in response to challenge than did transfer of cells from non-primed donors.

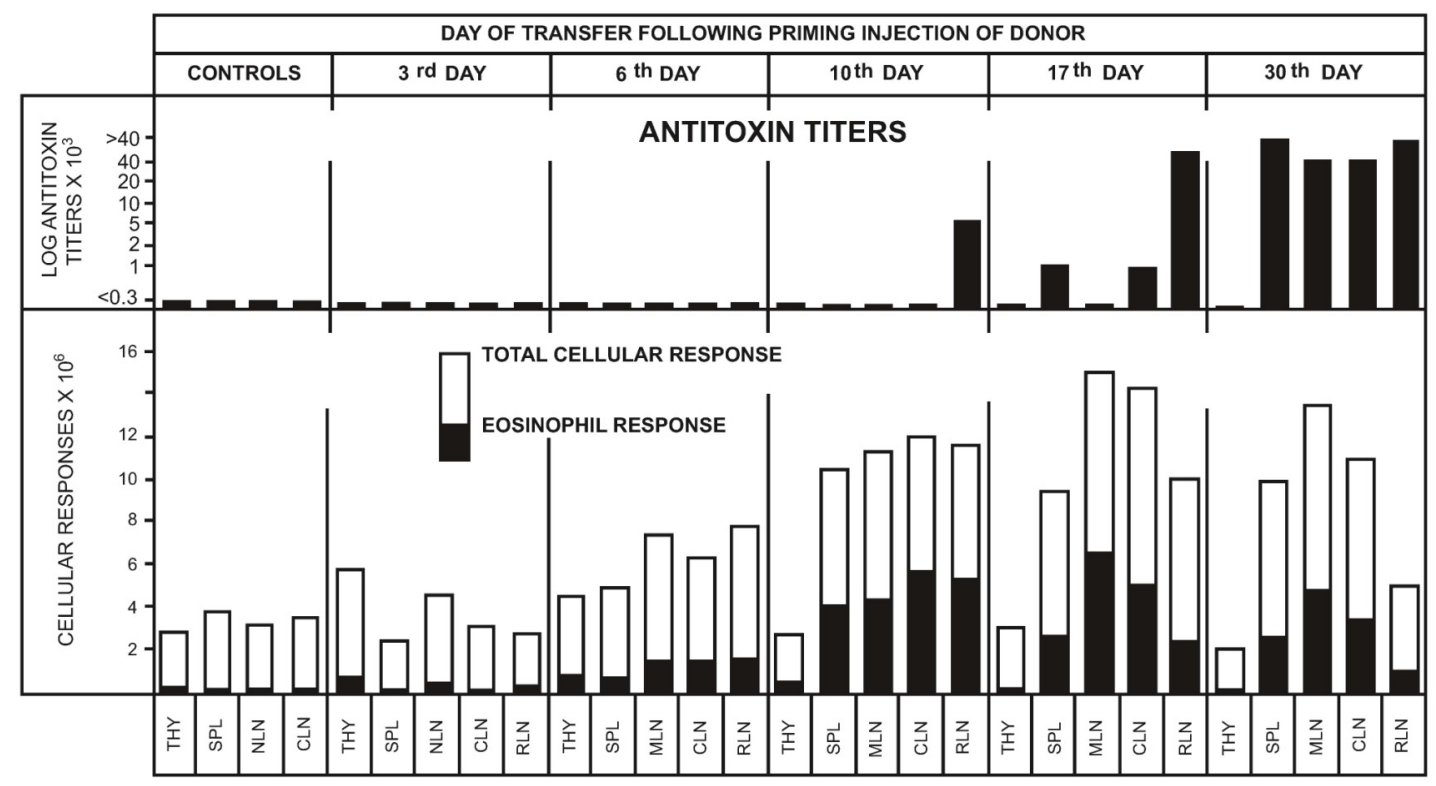

Fig. (6). Adoptive transfer of cells from various tissues at selected times after priming. The progeny of transferred cells provided the T and B memory cells enabling TIR mice to respond to a challenge injection of antigen. Abbreviations: Thy-Thymus; SPL-Spleen; MLN-Mesenteric Lymph Node; ILM-Inguinal LN; RLN-Regional LN; CLN-Contralateral Inguinal LN. 
In other experiments, selective removal of $\mathrm{T}$ lymphocytes from a population of primed spleen cells was accomplished by treatment with anti-Thy 1.2 serum plus complement (see Table 2). Such treatment prevented the secondary eosinophil responses as well as the secondary humoral antitoxin responses to tetanus toxoid, indicating the central role of $\mathrm{T}$ memory cells in both types of responses.

Table 2. Summary of Adoptive Transfer of Memory Cells Demonstrating Two Separate Memory Cell Populations, One Involved with the Anamnestic Eosinophil Response (T Cell) and a Second Involved with Antibody Production (B Cells)

\begin{tabular}{|c|c|c|c|c|c|}
\hline Ag & $\begin{array}{c}\text { Primed } \\
\text { T Cells }\end{array}$ & $\begin{array}{c}\text { Nä̈ve } \\
\text { T Cells }\end{array}$ & $\begin{array}{c}\text { Primed } \\
\text { B Cells }\end{array}$ & $\begin{array}{c}\mathbf{2}^{\mathbf{0}} \text { Eosinophil } \\
\text { Response }\end{array}$ & $\begin{array}{c}\mathbf{2}^{\mathbf{0}} \text { Antibody } \\
\text { Response }\end{array}$ \\
\hline \hline- & + & - & + & No & No \\
\hline+ & + & - & - & Yes & No \\
\hline+ & - & + & + & No & No \\
\hline+ & - & - & + & No & No \\
\hline+ & + & - & + & Yes & Yes \\
\hline
\end{tabular}

Abbreviations: Ag-Antigen; $2^{\circ}$-Secondary (anamnestic) response; plus (+) means presence and minus $(-)$ indicates absence of what is described in the column header.

The nature of the populations responsible for eosinophil and antibody responses was characterized by depleting $\mathrm{T}$ or $\mathrm{B}$ cells prior to transfer. The population involved with the anamnestic eosinophil response was inhibited by anti-T cell antibody plus complement but not by anti-B cell antibody plus complement. This indicated that the anamnestic eosinophil response required the presence of $\mathrm{T}$ cells. However, transfer of naive $\mathrm{T}$ cells and primed $\mathrm{B}$ cells did not induce humoral antitoxin, indicating that memory helper $\mathrm{T}$ cells were also necessary for anamnestic antibody responses. While $\mathrm{T}$ memory cells for eosinophil responses appeared earlier and spread more rapidly than $\mathrm{B}$ cells, both populations were necessary to initiate antitoxin production.

The role of B lymphocytes in immune reactions was also studied by treating primed spleen cells with anti-Ig serum and complement prior to adoptive transfer [65]. Such treatment inhibited humoral responses to both thymicdependent and thymic-independent antigens. When 30 day immune spleen cell suspensions were treated with anti-Ig serum plus complement prior to transfer, a prolonged eosinophil response was obtained even though the humoral response was prevented. When these immune spleen cells were treated with anti-Thy 1.2 and anti-Ig serum, both responses were inhibited. Addition of non-primed spleen cells failed to restore the anamnestic responses.

To determine if the CD4+ T memory cells that mediate the eosinophil response could also act as helper cells in $\operatorname{IgG}$ antibody production, 10 day immune spleen cells were combined with $\mathrm{T}$ cell-depleted 30 day immune cells. When transferred into TIR mice, these primed T cells, along with primed B cells, facilitated both the eosinophil response and IgG antibody production.

These results indicated that B memory cells needed the cooperation of memory $\mathrm{T}$ helper $(\mathrm{TH})$ cells in order to undergo the transformation into plasma cells. At the time these experiments were performed, TH cell subsets were not yet described. However, based on the subsequent characterization of TH1 and TH2 subsets and their cytokine patterns $[166,167]$, it became apparent that memory TH2 cells mediated the observed secondary responses described in these earlier studies. Antigen-challenged memory $\mathrm{TH}$ cells also induced high eosinophil responses at the time B memory cells were converting to plasma cells (Fig. 6), suggesting a role for eosinophils in the B cell transformation.

\section{GRANULOMA FORMATION}

The number of cells present in the peritoneal exudate following an i.p. injection of tetanus toxoid plus alum into previously immunized mice tended to diminish after about a week (see Fig. 2). By the end of the second week, the cell number was similar to that of non-injected controls [16, 168]. In contrast, serum IgG antibody was first detected 4 to 7 days after challenge, and the titers continued to rise for the next 6 to 8 weeks - long after the number of cells in the peritoneal exudate had begun to subside.

In order to study cellular interactions among the various cell types involved in the secondary response in tetanus toxoid-primed mice, the challenge antigen was absorbed onto activated charcoal, which facilitated identification of the granulomas that developed in the peritoneal cavity $[6$, 82]. These granulomas represented a localized manifestation of the secondary response to antigen, and initially contained populations of cells similar to those seen in the inflammatory exudate (see Fig. 7). By removing the granulomas at various times after antigen challenge, quantitative and qualitative analysis of their cellular content provided a sequential view of the ongoing cellular response. Coupled with measurement of serum titers of IgG anti-tetanus antibody, a comprehensive picture of cellular and humoral responses was attained.

Granulomas that formed locally after i.p. injection of antigen plus alum were removed, cell suspensions were prepared, and absolute cell numbers were determined by total cell counts and differential morphology. Granulomas induced by alum alone (left panels of Fig. 7), alum plus a primary exposure to tetanus toxoid (middle panels), and alum plus a secondary injection of tetanus toxoid (right panels) were compared. The greatest numbers of eosinophils and plasma cells were found in mice that received a second injection of specific antigen [45].

Subsequently, large blast cells, many undergoing mitosis and surrounded by eosinophils, were observed (see Figs. 8, 9). A few plasma cells were observed at 7 days, and they slowly increased in number until they became a major constituent, forming a cortex of cells around a medullary region of macrophages, cellular debris, antigen and a few neutrophils. The mononuclear cells in the cortex varied widely in size, shape, nuclear position and degree of cytoplasmic basophilia. Eventually, plasma cells predominated, forming as many as 10 layers of cells around the medullary area (Fig. 10).

Irradiated, syngeneic hosts receiving a granuloma transplant acquired the ability to synthesize antibody, as well as the capability to mount an anamnestic response when challenged with specific antigen $[45,83,169]$. These granulomas are therefore a local manifestation of the cells responsible for humoral immunity. 


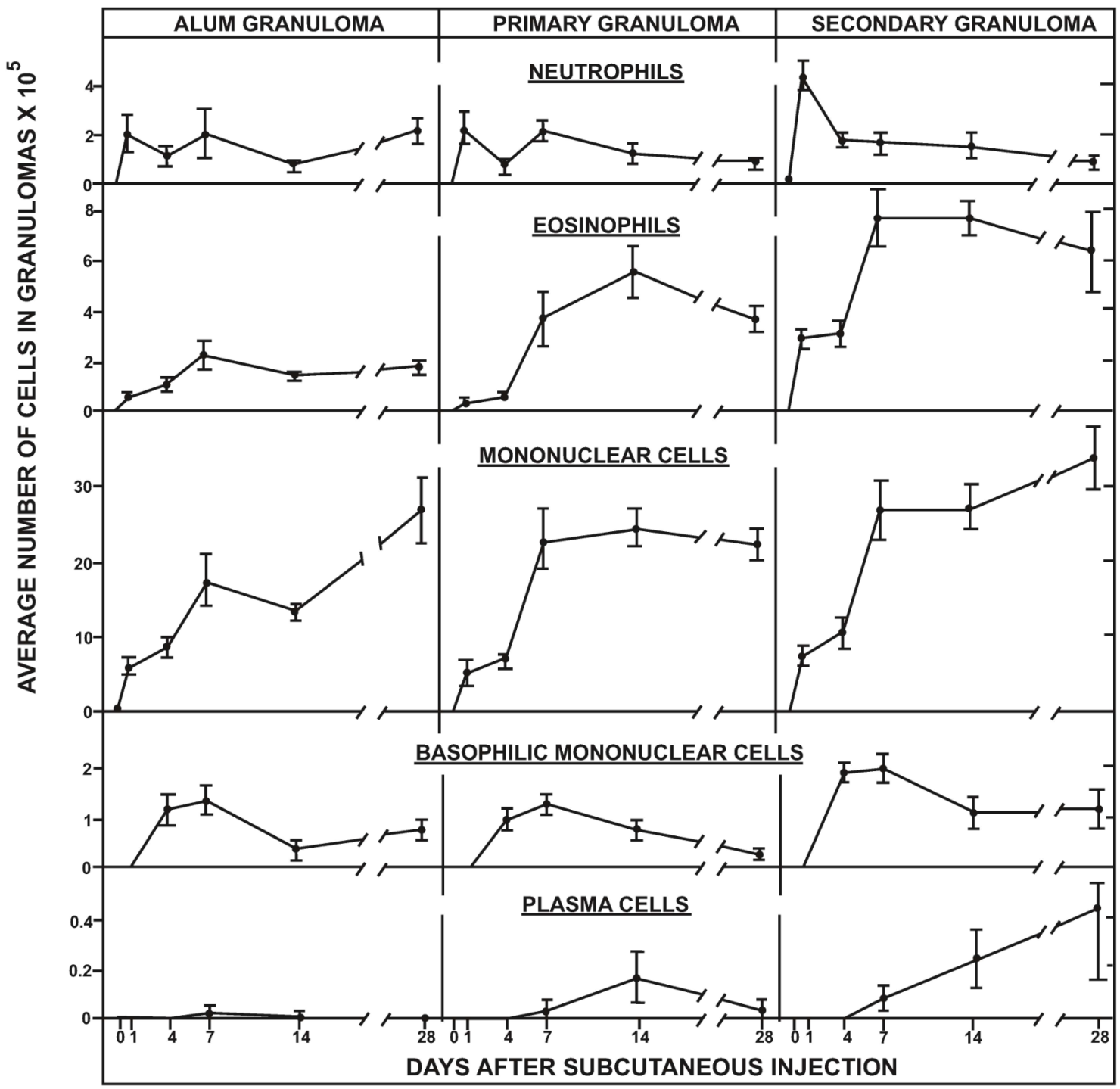

Fig. (7). Cellular composition of granulomas. The total number of each cell type is shown for alum controls (left column), primary granulomas (middle column), and secondary granulomas (right column).

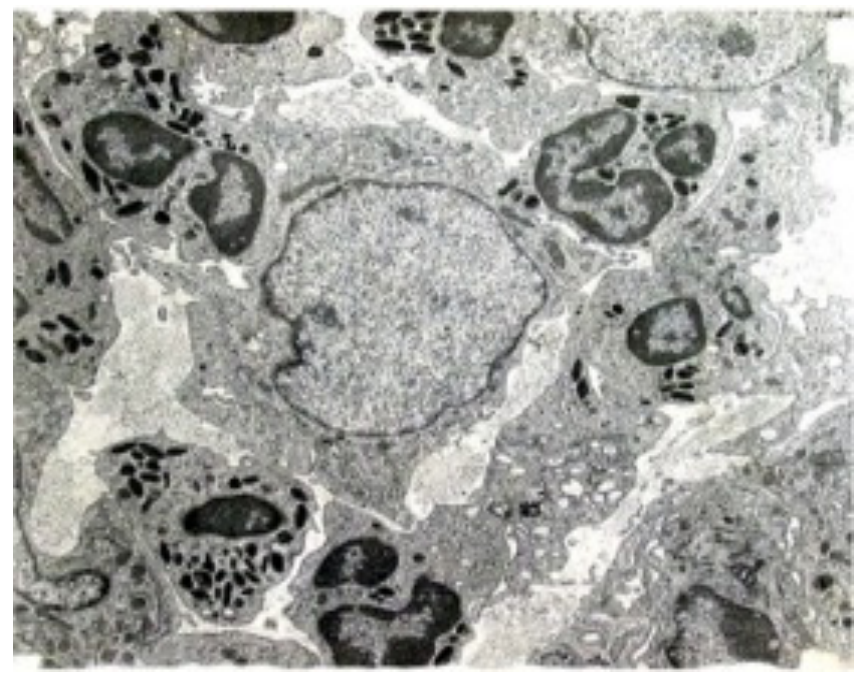

Fig. (8). Blast cell surrounded by eosinophils. In this electron micrograph 7 eosinophils surround the large mononuclear blast cell in the center of the micrograph.
In separate experiments $[6,83,170,171]$ similar plasma cell granulomas were induced in the subcutaneous region of mice by injections of tetanus toxoid mixed with adjuvant aluminum hydroxide or pertussis vaccine. Paul, et al. [45] estimated that in such granulomas the number of plasma cells increased by 2000 cells per day between the $4^{\text {th }}$ and the $28^{\text {th }}$ day after injection. These experiments demonstrated that granulomas represent a manifestation of the humoral immune response at the site of antigen injection. Since they persist for long periods, they serve as a prolonged source of antigenic stimulation necessary for sustaining serum antibody titers [172-176].

\section{CELL-TO-CELL COMMUNICATION DURING ADAP- TIVE IMMUNITY}

The presence of nucleic acids in the peripheral circulation has been known for a long time. However, the potential for RNA to carry information from one cell to another has been realized only recently [177-179]. The evidence suggests that RNA may supplement endocrine and paracrine signaling and act as an efficient and flexible source 
of sequence-specific informational transfer between cells, both locally and systemically. This represents a new mechanism of cell-cell communication in which the delivery of RNA occurs by transfer through nanotubes which connect one cell with its neighbor, and nano-vesicles called exosomes. These exosomes are released from diverse cell types into the extracellular milieu, and are found in blood, breast milk and urine [180-183].

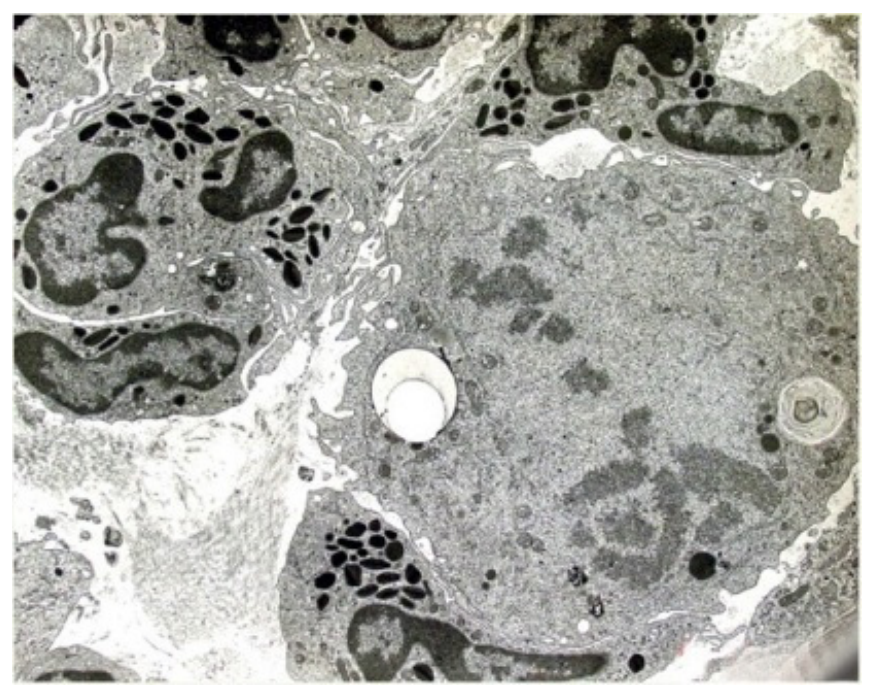

Fig. (9). Blast cell surrounded by eosinophils.

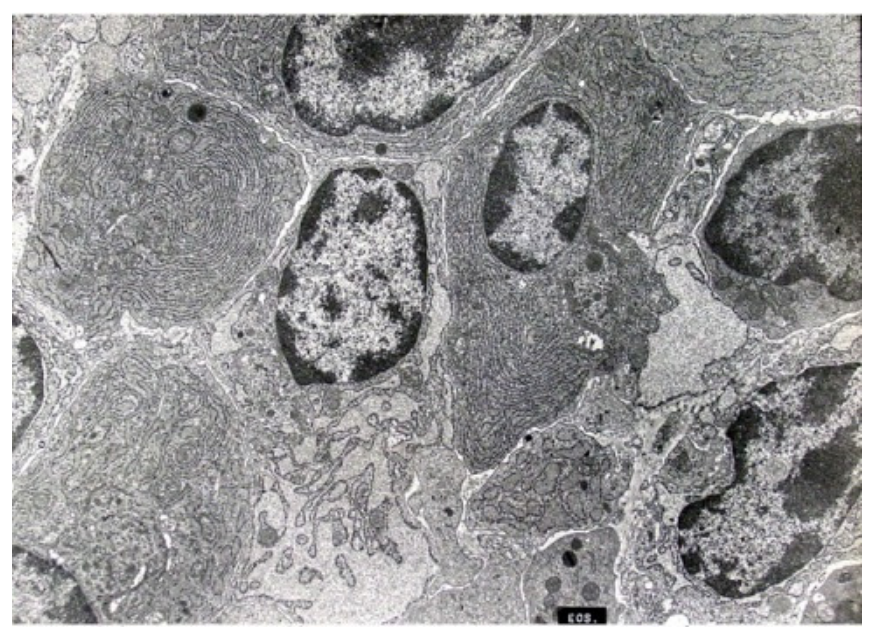

Fig. (10). Persistence of plasma cells in granulomas that develop in tetanus toxoid-primed mice following a challenge injection of tetanus antigen.

Exosomes are created intracellularly when an endosome containing many small vesicles fuses with the cell membrane, triggering the release of nano-sized vesicles $(<100 \mathrm{~nm})$. Once released, the vesicles are called exosomes and consist of a lipid raft embedded with ligands common to the original cell membrane. Exosomes are produced by many different cells, and cell components. Of special interest to this review are hematopoietic cells, such as dendritic cells, B cells, $\mathrm{T}$ cells, and mast cells, which have been shown to release exosomes $[184,185]$.

Isolated exosomes collectively contain thousands of different protein and RNA molecules, but little or no DNA has been reported. Exosomes from different cellular origins also bear distinct proteins of the producing cell. Some of the
RNA molecules are in the form of mRNA, which was demonstrated to be functional and could induce protein synthesis when transferred to another cell. This mRNA has been transferred from mouse to human mast cells, resulting in the production of mouse proteins by human cells [177].

A wide variety of RNA molecules of different sizes exist within isolated exosomes. Some appear to be the size of microRNA, and appear to be non-coded as far as currently known. Thus, exosomes appear to represent a vehicle by which one cell communicates with another by way of protein and RNA molecules, and delivers substances capable of modulating recipient-cell activity. Thus, there is increasing experimental evidence to suggest that RNA has been widely adopted as an intermediate regulatory molecule not just within cells, but also systemically, thereby forming an important component of the intercellular communication system [186].

It has also been shown that exosomes isolated from human EBV-transformed B cells can activate TH cells in an antigen-specific manner [187], and exosomes from antigenpulsed mouse APC Dendritic Cells can induce tumor immunity [188]. Therefore, it is possible that exosomemediated mechanisms can also result in transfer of RNA between memory TH cells and memory B cells. The RNA could then pass through the endoplasmic reticulum-Golgi secretory pathway, complexing with ribosomes, to form polyribosomes and become part of the Ig-forming mechanism in secondary antibody responses.

\section{CELLULAR REACTIONS LEADING TO PLASMA CELL FORMATION}

B cells capable of transforming into antibody-secreting plasma cells accumulate in specific areas of the body. Initially they are found in the granulomatous tissue associated with inflammation and in the regional lymph node(s). They then spread systemically to all lymph nodes, spleen and bone marrow and, in some cases, to nonlymphatic tissue $[111,143-145,158,189]$. Both $\mathrm{T}$ and $\mathrm{B}$ cells play a central role in humoral immunity to protein antigens [190,191]. The transformation of B memory cells to IgG-secreting plasma cells involves a loss of $\operatorname{IgM}$ membrane receptors and/or IgM secretion, a condensation of nuclear chromatin, a marked increase in RER and finally the switch to IgG antibody production/secretion. This transformation of B memory cells is mediated by cytokines released from $\mathrm{CD} 4$ memory $\mathrm{TH}$ cells. In addition to $\mathrm{T}$ and $\mathrm{B}$ cells, at least two other cell types, dendritic cells (DC) and eosinophils, also appear to be involved in this B cell transformation, since both cells contact $\mathrm{TH}$ cells and subsequently B memory cells.

TH2 memory cells, when activated by an antigenic epitope, release IL-5 which stimulates eosinophil replication and differentiation resulting in the production, packaging and storage of eosinophil-produced eokines [31]. One of these eokines, RNase-2, specifically attracts DCs into the inflammatory area $[122,123]$. These activated DCs produce and release additional chemokines, including IL-15, which stimulates B cell proliferation.

IL-5, combined with IL-2 and IL-6, all stored in the crystalloid core of eosinophil granules, are the main factors involved in the formation of Blimp-1, a transcription 
repressor protein and a master regulator of plasma cell differentiation [192, 193]. This cytostatic repressor inhibits on-going transcription and translation of mRNA in the $\mathrm{B}$ cells without being cytotoxic. Since B cell proliferation is stimulated by IL-15, the daughter cells contain ribosomes presumably capable of utilizing newly released mRNA coded for IgM [194-201]. B cells have the capacity to sequentially produce both membrane-bound and secreted forms of the Ig antigen receptor, depending upon pre-mRNA cleavage and splicing. Under the influence of cytokines and, perhaps, the uptake of exosomes containing antigen and/or mRNA originating from APC and TH2 memory cells, B cells can undergo additional gene rearrangements to switch their Ig isotype, and differentiate into antibody-producing plasma cells.

The inhibitory action of another eokine, RNase-3, on post-transcription mRNA could facilitate the rapid switch in protein synthesis from ongoing IgM synthesis to synthesis of IgG, IgA or IgE [104, 202-204]. RNase-3 (Eosinophil Cationic Protein) and MBP (Major Basic Protein) are of particular interest in this regard. RNase-3 is a single chain highly cationic glycoprotein that can be secreted into the extracellular medium. Both RNase-3 and MBP are toxic to some foreign agents (bacteria) and many tissue types since they damage cell membranes. However, they can also enter cells by a non-surface receptor-mediated mechanism and inhibit cell growth without necessarily causing cell death.

The B Cell Receptor (BCR) for antigen is normally composed of an antibody molecule with identical base pairs of antigen-binding sites, each containing two light and two heavy polypeptide chains, determined by a multiplicity of genes in a supergene family. The $\mathrm{T}$ cell receptor has only one antigen-binding site, determined by genes similar to the Ig genes in their organization and combinational diversity. The T cell Receptor (TCR) for antigen is a heterodimer with $95 \%$ of $\mathrm{T}$ cells expressing alpha and beta chains in their TCRs, and 5\% with TCRs consisting of gamma and delta chains.

Mature B lymphocytes exhibit allelic exclusion in which only a single isotype of Ig heavy chain and a single isotype of light chain ( $\kappa$ or $\lambda$ ) are expressed in the same cell. With the exception of naïve B cells that express both $\operatorname{IgM}$ and $\mathrm{IgD}$, this has been consistently observed as far as the heavy chain is concerned. However, recent reports document that dual light-chain expression and light chain shifting (or light chain gene rearrangements) can occur during this process, changing the specificity of the antibody [205, 206]. These exceptions are observed in normal human peripheral blood B cells [207], and also in B-cell malignant neoplasms, including chronic lymphocytic leukemia [208].

Light chain inclusion appears to be necessary for the terminal B cell differentiation into plasma cells. The light chain dependency and associated exceptions indicate that the development and expression of the light chain must be somewhat different from that of the heavy chain. This may involve the extracellular stimulus from the TH memory cell.

Although it has been demonstrated that surface molecules on activated memory $\mathrm{TH} 2$ cells interact with B cell surface molecules [209], transfer of information could also occur when antigen-activated memory $\mathrm{TH} 2$ cells undergo apoptosis/necrosis. During these cell interactions, $\mathrm{TH} 2$ memory cells release their cellular content, including the dsRNA containing RNA coded for $\mathrm{T}$ cell receptors, into the extracellular media. There is also a breakup and release of endosomes, forming exosomes containing the RNA.

This inflammatory milieu also contains RNAses and other enzymes released by activated eosinophils which had previously been attracted to the area. Memory TH cells, when stimulated, secrete high levels of RANTES, an eosinophil chemotactic and activating agent [210-212]. Moreover, in addition to the immediate release of preformed RANTES, synthesis and release of RANTES continues over a period of 40 days, thus maintaining high local levels of activated eosinophils in the inflammatory milieu.

Until recently, the cell membrane was considered an impermeable barrier for most macromolecules. However cell-penetrating peptides (CPPs) or protein transduction domains (PTDs) have recently been shown to cross the lipophilic barrier of cell membranes and carry cargos of nucleic acids, proteins and a wide variety of large molecules and small particles with them [43]. This cationic delivery system permits molecules to efficiently enter cells and function in the cytosol.

This is a non-surface receptor-mediated mechanism, which has been shown to be responsible for ferrying cytotoxic RNAse as well as RNA molecules into target cells [213-216]. It is possible that the CPPs in the inflammatory exudate could transport mRNA or even DNA from the disrupted CD4 T memory cells into the preplasma cells as they convert into plasma cells.

Association of DCs and eosinophils also appears likely given the fact that on re-exposure to antigen, the eosinophil response is augmented and an eokine, RNase-2, which specifically attracts DCs into the inflammatory area, is released [122, 123]. DCs are important APC for antigenic peptides in both the primary and anamnestic responses, and in the release of chemokines that affect B cell replication. Eosinophils are also present around activated $\mathrm{T}$ cells, and are observed during the early stages of granuloma formation. The eosinophils cluster around the dividing B memory cells prior to the period when plasma cells are forming.

In addition, eokines, Major Basic Protein (MBP), and RNase-2 have been shown to facilitate outer and inner membrane permeability to nutrients without apparently killing the targeted cells [217]. The eosinophils, and the release of their eokines, could contribute in some way to the adoptive transfer of information from memory $\mathrm{TH} 2$ cells to $\mathrm{B}$ memory cells as they transform into plasma cells.

\section{CORRELATION OF CONTEMPORARY RESULTS WITH THE ROLE OF EOSINOPHILS IN HUMORAL IMMUNE RESPONSES}

Based on results from current studies related to antigen processing, cell-cell and molecular interactions in humoral immune responses, we speculate how this information supports the role of eosinophils in antibody responses. We do this to stimulate further consideration and study of how eosinophils participate in the process of antibody production, particularly following a secondary exposure to antigen. 


\section{Formation and Properties of dsRNA}

Numerous studies [218-222] have shown that small RNA molecules (called RNAi, miRNA or siRNA) can anneal with mRNA, forming dsRNA, and complex with protein (mRNP). Moreover, these protein-RNA complexes are formed during the inductive phase of the immune response, and the protein component of these complexes is associated with antigenic epitopes [112, 223-225]. These complexes persisted for very long periods, and were found to be immunologically active both in vivo and in vitro. The mRNA complexes result in inactivated mRNA ( $m R N A$ silencing) without causing cell degradation, and could be processed and re-activated under appropriate conditions.

We propose that eosinophils could play a role in this process, since RNA complexes, such as dsRNA, have been shown to induce secretion of both RANTES and Eotaxin-3, which attract eosinophils [226, 227]. Eosinophils also release RNase-3 which specifically complexes with dsRNA [228]. RNase-3 has been shown to have a role in the stability and metabolism of mRNA [193, 229, 230].

During a secondary exposure to antigen, the transformation of B memory cells into plasma cells occurs in the presence of the eokines and dendritic cell chemokines released into the inflammatory area and into regional lymph nodes. Any nuclear dsRNA containing the inactivated mRNA formed during an earlier response to this antigen would be partially catabolized, and the released mRNA subjected to the editing mechanism of endonucleases and to splicing by spliceosomes [231, 232].

The released mRNA would be available for protein synthesis when it attaches to the B cell ribosomes, especially during mitosis when the nuclear membrane disappears, and this would explain the rapid switch from $\operatorname{IgM} / \mathrm{IgD}$ to $\mathrm{IgG}$ production. In addition, the B cell progeny with IgM and IgD receptors [233] would serve as memory $B$ cells that have been shown to produce high affinity $\operatorname{IgM}[234,235]$.

$\mathrm{T}$ cells also have mRNA specifically coded for the membrane receptor TCR, which is capable of complexing with antigenic epitopes. Complexes are also formed with RNAi, resulting in gene silencing of memory T cells [236]. After re-exposure to antigen, activated memory $\mathrm{TH}$ cells clonally expand and then undergo apoptosis, releasing their cellular content into the extracellular milieu. The memory TH cell dsRNA would be released in the presence of RNAses released by nearby eosinophils.

The results of these studies suggest that eosinophils with their assortment of eokines most likely have a regulatory role in anamnestic cellular responses.

\section{Toll-Like Receptors}

Toll-like Receptors (TLR) make up a family of patternrecognition receptors (PRRs) that sense pathogen-derived molecules or injured host cells. These germ-line-encoded transmembrane receptors are part of the signaling network that triggers the inflammatory, innate and adaptive immune responses that distinguish "friend" from "foe" [237-239]. They regulate responses in the extracellular matrix, and play a role in responses to endogenous stimuli such as necrotic cells and their contents. In vertebrates, TLRs transmit crucial information within $\mathrm{T}$ and $\mathrm{B}$ memory cells and associated inflammatory cells involved in adaptive immunity.

There is a "division of location and labor" among different TLRs, some predominating on the cell membrane while others recognize nucleic acids in the endosomes [240]. There is also a tendency to redundancy and synchronization with other signaling pathways. Specific cells of the inflammatory and immune systems appear to be capable of expressing unique TLRs, each with different reaction potential [241].

Of relevance to cells involved in the humoral immune response, TLR3 is expressed on dendritic cells, and reacts to necrotic or dying endogenous cells and to double stranded RNA [242, 243], and TLR7 and TLR8 bind single stranded RNA molecules [244, 245]. TLR expression can vary greatly in the same cell at different stages of differentiation. In naive B cells, for example, TLRs are expressed at low or undetectable levels, but upon BCR triggering they rapidly upregulate the TLRs and express TLR9 and TLR10 [246]. B memory cells express several TLRs at high levels.

Eosinophils also express a variety of TLRs, including TLRs $1,3,4,7,9$ and 10 , as shown by both expression of mRNA and proteins [247-249]. Eosinophils activated by TLR ligands that mimic bacterial $(\mathrm{CpG})$ and viral (poly $\mathrm{I}: \mathrm{C}$ ) stimuli exhibit prolonged survival, up-regulated expression of adhesion molecule CD11b, and increased secretion of IL8 [249]. Such activation of eosinophils via their TLR has been suggested as a mechanism for allergy-associated inflammation [248, 249]. As described earlier in this review, activated eosinophils also produce a variety of other antimicrobial proteins, including Eosinophil-Derived Neurotoxin (EDN). EDN can attract dendritic cells to inflammatory sites, and activate them, resulting in enhanced antigen-specific, TH2-polarized humoral immune responses [250].

Therefore, in the context of the experiments described above in which a robust eosinophil response precedes the production of antibody following a challenge injection of tetanus toxoid in previously immunized mice (see Fig. 3), we propose that eosinophils play some type of regulatory role in adaptive immunity. We speculate that in such "memory" immune responses, eosinophils would be activated via their TLR, and produce mediators that attract and activate dendritic cells and other APC to facilitate the observed secondary humoral immune response.

\section{Knockout (KO) Mice}

Genetically altered KO strains of mice provide valuable research tools to determine the role of a specific gene by observing the phenotype of mice that completely lack the gene. Recent work with KO mice clearly demonstrates that eosinophils play a central regulatory role in chronic allergic inflammation [51].

For example, IL-5 stimulation is required for the secondary type eosinophil response that is a component of the protective immune response to parasites [251-253]. However, IL-5-deficient KO mice subjected to a challenging Strongyloides stercoralis larvae infection demonstrated very little increase in eosinophils and were unable to develop protective immunity $[254,255]$. Eosinophils injected at the 
time of challenge resulted in a reconstitution of immune capacity. These eosinophils did not appear to participate in the actual killing of the larvae, but were responsible for the induction of both parasite-specific IgM and IgG responses. Other experiments using $\mathrm{KO}$ mice demonstrate that eosinophils play an important role in $\operatorname{Ig} \mathrm{A}$ and $\operatorname{IgE}$ formation [256-259] following prolonged or repeated exposure to antigenic material.

In summary, studies utilizing KO mice strongly indicate that IL-5 release and the resultant eosinophil response have a role in the formation of antibody during the protective immune responses to $\mathrm{T}$ cell dependent antigens. These results support the likelihood that eosinophils participate in secondary antibody responses to other antigens, including protein antigens.

\section{SUMMARY AND CONCLUSIONS}

Adaptive immunity involves a process by which the presence of a foreign protein induces highly specific humoral antibody formation by the coordination of specialized cells which originate primarily in the myeloid and lymphoid tissues. Our knowledge of these cells, their actions, reactions and intercellular communications is now extensive, and it is challenging to utilize these facts to help understand the cellular progression leading to humoral immunity.

Although they have not been seriously considered important to the process of adaptive humoral immunity, eosinophils are a consistent component of the response to protein antigens. This review describes the pattern of cellular responses and interactions leading to specific humoral antibody formation, and proposes a role for eosinophils and their cytokines and chemokines in the process. It broadens the stage for further experiments to evaluate concepts regarding the mechanisms involved in adaptive immunity.

Current data indicate that in a primary immune response, exposure to antigen results in expansion of selected clones of $\mathrm{T}$ and $\mathrm{B}$ cells, and the formation of mRNA coded for their antigen-binding receptors TCR and BCR, respectively [6872]. This is a DNA-dependent process since the presence of Actinomycin $\mathrm{D}$ has been shown to completely block priming to the antigen [89-93]. On the other hand Actinomycin D had little or no effect on blocking the humoral antitoxin response during the anamnestic response, demonstrating a distinct difference in sensitivity to the Actinomycin D once memory cells were formed.

The data suggest that priming results in the formation of double stranded RNA (dsRNA) complexes, induced by annealing the mRNA with RNAi (miRNA or siRNA) [260] which are stored in the speckles or granules within the vesiculated nuclei of memory $\mathrm{T}$ cells [261]. These complexes consist of dsRNA and a protein which may be a component of the initiating antigenic molecule [225].

During the anamnestic response to the antigenic epitopes, memory $\mathrm{T}$ and $\mathrm{B}$ cells undergo clonal expansion. Replication of memory TH2 cells is followed by apoptosis/necrosis [8082] while B memory cell replication is followed by differentiation into plasma cells $[6,83,93]$. Breakdown of the memory TH2 cells results in the release of cell contents, including stored dsRNA complexes [262], into the inflammatory exudate where they can be catabolized by
EPO, RNAse-3, and other enzymes released by eosinophils. This results in the formation of soluble single stranded coded RNA which has the capacity to complex with TLR on memory B cells and their progeny [243, 263, 264].

We postulate that the coded RNA would then pass along the endoplasmic reticulum-Golgi pathway complexing with ribosomes created by mitotic division in the activated memory B cells. This would result in the formation of new polyribosomes and initiate translation of the coded RNA into a component of the antibody molecule without requiring further DNA-dependent RNA transcription.

In summary, analysis of data accumulated from different laboratories over a span of many years strongly indicates that eosinophils, along with $\mathrm{T}$ and $\mathrm{B}$ lymphocytes, macrophages and dendritic cells, do have an important immunoregulatory role in memory B cell transformation into plasma cells, and the initiation of $\mathrm{T}$ cell-dependent $\mathrm{IgG}$ antibody responses.

\section{ACKNOWLEDGEMENTS}

We thank Atara Marzouk and Eliza Lamin for help in the preparation of our manuscript.

\section{REFERENCES}

[1] Speirs RS. Physiological approaches to an understanding of the function of eosinophils and basophils. Ann NY Acad Sci 1955; 59: 706-31.

[2] Speirs RS, Speirs EE. Cellular localization of radioactive antigen in immunized and nonimmunized mice. J Immunol 1963; 90: 561-75.

[3] Speirs RS, Speirs EE. Cellular reactions to reinjection of antigen. J Immunol 1964; 92: 540-9.

[4] Speirs RS. How cells attack antigens. Sci Am 1964; 210: 58-64.

[5] Speirs R. Cellular aspects of immune reactions. Bio Sci 1969; 19 : 411-7.

[6] Speirs RS, Speirs EE. Quantitative studies of inflammation and granuloma formation. In: Van Arman CG, Ed. White Cells in Inflammation. Springfield: Thomas, C C 1973; pp. 54-92.

[7] Morel PA, Feili-Hariri M, Coates PT, Thomson AW. Dendritic cells, $\mathrm{T}$ cell tolerance and therapy of adverse immune reactions. Clin Exp Immunol 2003; 133: 1 .

[8] Hogan S, Rosenberg HF, Moqbel R, et al. Eosinophils: biological properties and role in health and disease. Clin Exp Allergy 2008; 38: 709-50.

[9] Trivedi S, Lloyd D. Eosinophils in the pathogenesis of allergic airways disease. Cell Mol Life Sci 2007; 64: 1269-89.

[10] Jacobsen E, Ochkur S, Lee N, Lee J. Eosinophils and asthma. Curr Allergy Asthma Rep 2007; 7: 18-26.

[11] Foster P, Rosenberg HF, Asquith K, Kumar R. Targeting eosinophils in asthma. Curr Mol Med 2008; 8: 585-90.

[12] Bruschi F, Korenaga M, Watanabe N. Eosinophils and Trichinella infection: toxic for the parasite and the host? Trends Patasitol 2008; 24: 462-7.

[13] Anthony R, Rutitzky L, Urban J, Stadecker M, Gause W. Protective immune mechanisms in helminth infection. Nat Rev Immunol 2007; 7: 975-87.

[14] Panzenhagen H, Speirs R. Effect of horse serum, adrenal hormones, and histamine on the number of eosinophils in the blood and peritoneal fluid of mice. Blood 1953; 8: 536-44.

[15] Speirs RS, Wenck U. Eosinophil response to toxoids in actively and passively immunized mice. Proc Soc Exp Biol Med 1955; 90: 571-4.

[16] Speirs R, Dreisbach M. Quantitative studies of the cellular responses to antigen injections in normal mice: technic for determining cells in the peritoneal fluid. Blood 1956; 11: 44-55.

[17] Dreisbach ME, Snell GD, Speirs RS. Quantitative studies of the local cellular response to isoantigens. J Natl Cancer Inst 1956; 17: 297303.

[18] Speirs R. A theory of antibody formation involving eosinophils and reticuloendothelial cells. Nature 1958; 181: 681-2.

[19] Kroegel C, Warner JA, Virchow JJC, Matthys H. Pulmonary immune cells in health and disease: the eosinophil leucocyte (Part II). Eur Resp J 1994; 7: 743-60. 
[20] Bandeira-Melo C, Weller P. Mechanisms of eosinophil cytokine release. Mem Inst Oswaldo Cruz 2005; 100(Suppl 1): 73-81.

[21] Spencer J, Szela C, Perez S, et al. Human eosinophils constitutively express multiple Th1 and Th2, and immunoregulatory cytokines that are secreted rapidly and differentially. J Leuk Biol 2009; 85: 117-23.

[22] Shi H-Z, Humbles A, Gerard C, Jin Z, Weller P. Lymph node trafficking and antigen presentation by endobronchial eosinophils. $\mathrm{J}$ Clin Invest 2000; 105: 945-53.

[23] MacKenzie J, Mattes J, Dent L, Foster P. Eosinophils promote allergic disease of the lung by regulating $\mathrm{CD} 4(+) \mathrm{Th} 2$ lymphocyte function. J Immunol 2001; 167: 3146-55.

[24] Shi H-Z. Eosinophils function as antigen-presenting cells. J Leuk Biol 2004; 76: 520-7.

[25] Padigel U, Lee J, Nolan T, Schad G, Abraham D. Eosinophils can function as antigen-presenting cells to induce primary and secondary immune responses to strongyloides stercoralis. Infect Immun 2006; 74: 3232-8.

[26] Speirs RS, Osada Y, Jensen V. DNA synthesis in inflammatory cells of immunized and nonimmunized mice. Proc Soc Exp Biol Med 1961; 106: 251-5.

[27] Speirs RS, Meyer RK. The effects of stress, adrenal and adrenocorticotrophic hormones on the circulating eosinophils of mice. Endocrinology 1949; 45: 403-29.

[28] Speirs R, Wenck U, Dreisbach ME. Quantitative studies of the cellular responses to antigen injections in adrenalectomized mice. Blood 1956; 11: 56-70

[29] Del Pozo V, De Andres B, Martin E, et al. Murine eosinophils and IL-1: $\alpha$ IL-1 mRNA detection by in situ hybridization. Production and release of IL-1 from peritoneal eosinophils. J Immunol 1990; 144:3117-22.

[30] Moqbel R, Coughlin J. Differential secretion of cytokines. Sci STKE 2006; 2006: 26.

[31] Lacy P, Moqbel R. Eokines: synthesis, storage and release from human eosinophils. Mem Inst Oswaldo Cruz 1997; 92(Suppl 2): 12533.

[32] Lacy P, Levi-Schaffer F, Mahmudi-Azer S, et al. Intracellular localization of interleukin-6 in eosinophils from atopic asthmatics and effects of interferon $\gamma$. Blood 1998; 91: 2508-16.

[33] Woerly G, Roger N, Loiseau S, Capron M. Expression of Th1 and Th2 immunoregulatory cytokines by human eosinophils. Int Arch Allergy Immunol 1999; 118: 95-7.

[34] Chen L, Grabowski KA, Xin J-p, et al. IL-4 induces differentiation and expansion of Th2 cytokine-producing eosinophils. J Immunol 2004; 172: 2059-66

[35] Spencer L, Melo R, Perez S, Bafford S, Dvorak A, Weller P. Cytokine receptor-mediated trafficking of preformed IL-4 in eosinophils identifies an innate immune mechanism of cytokine secretion. Proc Natl Acad Sci USA 2006; 103: 3333-8.

[36] Lacy P, Mahmudi-Azer S, Bablitz B, et al. Rapid mobilization of intracellularly stored RANTES in response to interferon- $\gamma$ in human eosinophils. Blood 1999; 94: 23-32.

[37] Bandeira-Melo C, Anne Herbst A, Weller P. Eotaxins-contributing to the diversity of eosinophil recruitment and activation. Am J Respir Cell Mol Biol 2001; 24: 653-7.

[38] Heath H, Qin S, Rao P, et al. Chemokine receptor usage by human eosinophils: the importance of CCR3 demonstrated using an antagonistic monoclonal antibody. J Clin Invest 1997; 99: 178-84.

[39] Conroy D, Humbles A, Rankin S, et al. The role of the eosinophilselective chemokine, eotaxin, in allergic and non-allergic airways inflammation. Mem Inst Oswaldo Cruz 1997; 92(Suppl II): 183-91.

[40] Badewa A, Hudson C, Heiman A. Regulatory effects of eotaxin, eotaxin-2, and eotaxin-3 on eosinophil degranulation and superoxide anion generation. Exp Biol Med 2002; 227: 645-51.

[41] Mochizuki M, Bartels J, Mallet A, Christophers E, Schroder JM. IL-4 induces eoxatin: a possible mechanism of selective eosinphil recruitment in helminth infection and atopy. J Immunol 1998; 160: 60-8.

[42] Evans E, Harmon B. A review of antimicrobial peptides: defensins and related cationic peptides. Vet Clin Pathol 1995 ; 24: 109-16.

[43] Wagstaff KM, Jans DA. Protein transduction: Cell penetrating peptides and their therapeutic applications. Curr Med Chem 2006; 18: 1371-87.

[44] Speirs R. Examination of the mechanism of antibody formation using nucleic acid and protein inhibitors. Nature 1965; 207: 371-4.
[45] Paul SD, Athanassiades TJ, Speirs RS. A quantitative procedure for the study of cells in experimentally induced granulomas. Proc Soc Exp Biol Med 1972; 139: 1090-5.

[46] Jacobsen E, Taranova A, Lee N, Lee J. Eosinophils: singularly destructive effector cells or purveyors of immunoregulation? Allergy Clin Immunol 2007; 119: 1313-220.

[47] Akuthota P, Wang H, Spencer L, Weller P. Immunoregulatory roles of eosinophils: a new look at a familiar cell. Clin Exp Allergy 2008; 38: $1254-63$.

[48] Rothenberg M, Hogan S. The eosinophil. Ann Rev Immunol 2006; 24: $147-74$.

[49] Arnason BG, Waksman BH. The retest reaction in delayed sensitivity. Lab Invest 1963; 12: 737-47.

[50] Adamko DJ, Odemuyiwa SO, Vethanayagam D, Moqbel A. The rise of the phoenix: the expanding role of the eosinophil in health and disease. Allergy 2005; 60: 13-22.

[51] Fulkerson P, Fischetti C, McBride M, Hassman L, Hogan S, Rothenberg M. A central regulatory role for eosinophils and the eotaxin/CCR3 axis in chronic experimental allergic airway inflammation. Proc Natl Acad Sci USA 2006; 103: 16418-23.

[52] Rothwell TL, Dineen JK. Cellular reactions in guinea-pigs following primary and challenge infection with Trichostrongylus colubriformis with special reference to the roles played by eosinophils and basophils in rejection of the parasite. Immunology 1972; 22: 733-45.

[53] Behm C, Ovington K. The role of eosinophils in parasitic helminth infections: insights from genetically modified mice. Parisitol Today 2000; $16: 202-9$

[54] Rosenberg HF, Domachowske JB. Eosinophils, ribonucleases and host defense: solving the puzzle. Immunol Res 1999; 20: 261-74.

[55] Rosenberg H, Domachowske J. Eosinophils, eosinophil ribonucleases, and their role in host defense against respiratory virus pathogens. J Leuk Biol 2001; 70: 691-8.

[56] Pumputiene I, Emuzyte R, Dubakiene R, Firantiene R, Tamosiunas $\mathrm{V}$. T cell and eosinophil activation in mild and moderate atopic and nonatopic children's asthma in remission. Allergy 2006; 61: 43-8.

[57] Walsh GM. Eosinophil granule proteins and their role in disease. Curr Opin Hematol 2001; 8: 28-33.

[58] Costain DJ, Guha AK, Liwski RS, Lee TD. Murine hypodense eosinophils induce tumour cell apoptosis by a granzyme B-dependent mechanism. Cancer Immunol Immunother 2001; 50: 293-9.

[59] Linch S, Kelly A, Danielson E, Pero R, Lee J, Gold J. Mouse eosinophils possess potent antibacterial properties in vivo. Infect Immun 2009; 77(11): 4976-82.

[60] Herbert DB, Lee J, Lee N, Nolan T, Schad G, Abraham A. Role of IL-5 in innate and adaptive immunity to larval strongyloides stercoralis in mice. J Immunol 2000; 165: 4544-51.

[61] Galioto A, Hess J, Nolan T, Schad G, Lee J, Abraham D. Role of eosinophils and neutrophils in innate and adaptive protective immunity to larval strongyloides stercoralis in mice. Infect Immun 2006; 74: 5730-8.

[62] Matsunaga Y, Shono M, Takahashi M, Tsuboi Y, Ogawa K, Yamada $\mathrm{T}$. Regulation of lymphocyte proliferation by eosinophils via chymotrypsin-like protease activity and adhesion molecule interaction. Br J Pharm 2000; 130: 1539-46.

[63] Piliponsky A, Gleich G, Bar I, Levi-Schaffer F. Effects of eosinophils on mast cells: a new pathway for the perpetuation of allergic inflammation. Mol Immunol 2002; 38: 1369 .

[64] Puxeddu I, Ribatti D, Crivellato E, Levi-Schaffer F. Mast cells and eosinophils: a novel link between inflammation and angiogenesis in allergic diseases. J Allergy Clin Immunol 2005; 116: 531-6.

[65] Ponzio NM, Speirs RS. Lymphoid cell dependence of eosinophil response to antigen. VI. The effect of selective removal of T or B lymphocytes on the capacity of primed spleen cells to adoptively transferred immunity to tetanus toxoid. Immunology 1975; 28: 24351

[66] Castellino F, Germain R. Cooperation between CD4+ and CD8+ T cells: when, where, and how. Ann Rev Immunol 2006; 24: 519-40.

[67] Speirs RS, Turner MX. The eosinophil response to toxoids and its inhibition by antitoxin. Blood 1969; 34: 320-30.

[68] Bar-Or A, Oliveira E, Anderson D, et al. Immunological memory: contribution of memory B cells expressing costimulatory molecules in the resting state. J Immunol 2001; 167: 5669-77.

[69] Lipscomb M, Masten B. Dendritic cells: immune regulators in health and disease. Physiol Rev 2002; 82: 97-130. 
[70] Guermonprez P, Valladeau J, Zitvogel L, Théry C, Amigorena S. Antigen presentation and $\mathrm{T}$ cell stimulation by dendritic cells. Ann Rev Immunol 2002; 20: 621-67.

[71] Trombetta E, Mellman I. Cell biology of antigen processing in vitro and in vivo. Ann Rev Immunol 2005; 23: 975-1028.

[72] Rossi M, Young J. Human dendritic cells: potent antigen-presenting cells at the crossroads of innate and adaptive immunity. J Immunol 2005; 175: 1373-81.

[73] McHeyzer-Williams L, McHeyzer-Williams M. Antigen-specific memory B cell development. Ann Rev Immunol 2005; 23: 487-513.

[74] Dooms H, Abbas A. Control of CD4+ T-cell memory by cytokines and costimulators. Immunol Rev 2006; 211: 23-38.

[75] Sprent J, Surh C. T cell memory. Ann Rev Immunol 2002; 20: 55179.

[76] Macallan DC, Wallace DL, Zhang Y, et al. B-cell kinetics in humans: rapid turnover of peripheral blood memory cells. Blood 2005; 105: $3633-40$

[77] Anderson S, Tomayko M, Shlomchik M. Intrinsic properties of human and murine memory B cells. Immunol Rev 2006; 211: 28094.

[78] Stockinger B, Bourgeois C, Kassiotis G. CD4+ memory T cells: functional differentiation and homeostasis. Immunol Rev 2006; 211 : $39-48$.

[79] Littman DR, Singh H. Asymmetry and immune memory. Science 2007; 315: 1673-4

[80] Pelletier M, Girard D. Differential effects of IL-5 and Il-21 in

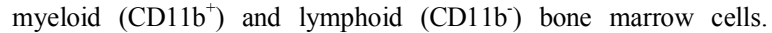
Immunology 2006; 177: 100-8.

[81] Jin H, Malek TR. Redundant and unique regulation of activated mouse B lymphocytes by IL-4 and IL-21. J Leuk Biol 2006; 80: 1416-23.

[82] Speirs RS. Function of leucocytes in inflammation. In: Gordon AS, Ed. Regulation of Hematopoiesis. New York: Appleton-CentryCrafts 1970; pp. 995-1043.

[83] Athanassiades TJ, Speirs RS. Granuloma induction in the peritoneal cavity. A model for the study of inflammation and plasmacytopoiesis in nonlymphatic organs. J Reticuloendothel Soc 1972; 11: 60-76.

[84] Wang JM, Rambaldi A, Biondi A, Chen ZG, Sanderson CJ, Mantovani A. Recombinant human interleukin 5 is a selective eosinophil chemoattractant. Eur J Immunol 1989; 19: 701-5.

[85] Williams T. The eosinophil enigma. J Clin Invest 2004; 113: 507-9.

[86] Louahed J, Zhou Y, Maloy W, et al. Interleukin 9 promotes influx and local maturation of eosinophils. Blood 2001; 97: 1035-42.

[87] Smiley JD, Heard JG, Ziff M. Effect of actinomycin d on RNA synthesis and antibody formation in the anamnestic response in vitro. J Exp Med 1964; 119: 891-3.

[88] Makinodan T, Santos G, Quinn R. Immunosuppresive drugs. Pharm Rev 1970; 22: 189-247.

[89] Geller BD, Speirs RS. Failure of actinomycin d to inhibit antitoxin production to a challenging injection of antigen. Proc Soc Exp Biol Med 1964; 117: 782-5.

[90] Speirs RS. Effect of actinomycin d upon the immune responses to tetanus toxoid. Life Sci 1965; 4: 343-9.

[91] Geller BD, Speirs RS. The effect of actinomycin-D on the haemopoietic and immune response to tetanus toxoid. Immunology $1968 ; 15: 707-16$.

[92] Geller BD, Speirs RS. Actinomycin D inhibition of mononuclear cell response to antigen. J Reticuloendothel Soc 1968; 5: 61-7.

[93] Paul SD, Athanassiades TJ, Speirs RS. The immunosuppressive effect of dactinomycin on experimentally induced granulomas: a quantitative study. Proc Soc Exp Biol Med 1973; 143: 222-9.

[94] Speirs RS, Osada Y. Chemotactic activity and phagocytosis of eosinophils. Proc Soc Exp Biol Med 1962; 109: 929-32.

[95] Speirs R. Antigenic material: persistence in hypersensitive cells. Science 1963; 140: 71-2.

[96] Jego G, Bataille R, Pellat-Deceunynck C. Interleukin-6 is a growth factor for nonmalignant human plasmablasts. Blood 2001; 97: 181722 .

[97] Kikuchi Y, Yasue T, Miyake K, Kimoto M, Takatsu K. CD38 ligation induces tyrosine phosphorylation of Bruton tyrosine kinase and enhanced expression of interleukin 5-receptor $\alpha$ chain: synergistic effects with interleukin 5. Proc Natl Acad Sci USA 1995; 92: 11814-8.

[98] Jego G, Pascual V, Palucka A, Banchereau J. Dendritic cells control B cell growth and differentiation. Curr Dir Autoimmun 2005; 8: 12439.
[99] Mizoguchi C, Uehara S, Akira S, Takatsu K. IL-5 induces IgG1 isotype switch recombination in mouse CD38-activated sIgD-positive B lymphocytes. J Immunol 1999; 162: 2812-9.

[100] Levi-Schaffer F, Barkans J, Newman TM, et al. Identification of interleukin-2 in human peripheral blood eosinophils. Immunology 1996; 87: 155-61.

[101] Lenardo M. Interleukin-2 programs mouse $[\alpha][\beta]$ T lymphocytes for apoptosis. Nature 1991; 353: 858-61.

[102] Razvi ES, Welsh RM. Programmed cell death of T lymphocytes during acute viral infection: a mechanism for virus-induced immune deficiency. J Virol 1993; 67: 5754-65.

[103] Zambricki E, Shigeoka A, Kishimoto H, et al. Signaling T-cell survival and death by IL-2 and IL-15. Am J Transplant 2005; 5: 2623-31.

[104] Kimata H, Yoshida A, Ishioka C, Jiang Y, Mikawa H. Inhibition of ongoing immunoglobulin production by eosinophil cationic protein. Clin Immunol Immunopathol 1992; 64: 84-8.

[105] Moller G, de Jong T, Overbeek S, van der Kwast T, Postma D Hoogsteden H. Ultrastructural immunogold localization of interleukin 5 to the crystalloid core compartment of eosinophil secondary granules in patients with atopic asthma. J Histochem Cytochem 1996; 44: 67-9.

[106] Jelinek D, Lipsky P. The role of B cell proliferation in the generation of immunoglobulin- secreting cells in man. J Immunol 1983; 130: 2597-604.

[107] Erickson L, Foy T, Waldschmidt T. Murine B1 B cells require IL-5 for optimal T cell-dependent activation. J Immunol 2001; 166: 15319.

[108] Calame KL. Plasma cells: finding new light at the end of B cell development. Nat Immunol 2001; 2: 1103-8.

[109] Calame K. Transcription factors that regulate memory in humoral responses. Immunol Rev 2006; 211: 269-79.

[110] Moon B-G, Takaki S, Miyake K, Takatsu K. The role of IL-5 for mature B-1 cells in homeostatic proliferation, cell survival, and Ig production. J Immunol 2004; 172: 6020-9.

[111] Jenkins MK, Khoruts A, Ingulli E, et al. In vivo activation of antigenspecific CD4 T cells. Ann Rev Immunol 2001; 19: 23-45.

[112] Fishman M. Antibody formation in vitro. J Exp Med 1961; 114: 856937.

[113] Volkman DJ, Lane HC, Fauci AS. Antigen-induced in vitro antibody production in humans: a model for $B$ cell activation and immunoregulation. Proc Natl Acad Sci USA 1981; 78: 2528-31.

[114] Konthur Zn, Hust M, Dübel S. Perspectives for systematic in vitro antibody generation. Gene 2005; 364: 19-29.

[115] Lambrecht BN, De Veerman M, Coyle AJ, Gutierrez-Ramos JC, Thielemans K, Pauwels RA. Myeloid dendritic cells induce Th2 responses to inhaled antigen, leading to eosinophilic airway inflammation. J Clin Invest 200; 106: 551-9.

[116] Malmgaard L. Dendritic cells, toll-like receptors, and T-cell responses: lessons from viral infections in vivo. Viral Immunol 2005; 18: 584-94.

[117] Bonasio R, Von Andrian U. Generation, migration and function of circulating dendritic cells. Curr Opin Immunol 2006; 18: 503-11.

[118] Granucci F, Foti M, Ricciardi-Castagnoli P. Dendritic cell biology. Adv Immunol 2005; 88: 193-233.

[119] Katsnelson A. Kicking off adaptive immunity: the discovery of dendritic cells. J Exp Med 2006; 203: 1622.

[120] Naik SH, Metcalf D, Nieuwenhuijze V, et al. Intrasplenic steady-state dendritic cell precursors that are distinct from monocytes. Nat Immunol 2006; 7: 663-71.

[121] Park C-S, Yoon S-O, Armitage R, Choi Y. Follicular dendritic cells produce IL-15 that enhances germinal center B cell proliferation in membrane-bound form. J Immunol 2004; 173: 6676-83.

[122] Yang D, Rosenberg H, Chen Q, Dyer K, Kurosaka K, Oppenheim J. Eosinophil-derived neurotoxin (EDN), an antimicrobial protein with chemotactic activities for dendritic cells. Blood 2003; 102: 3396-403.

[123] Yang D, Chen Q, Rosenberg HF, et al. Human ribonuclease a superfamily members, eosinophil-derived neurotoxin and pancreatic ribonuclease, induce dendritic cell maturation and activation. J Immunol 2004; 173: 6134-42.

[124] Burton G, Conrad D, Szakal A, Tew J. Follicular dendritic cells and B cell costimulation. J Immunol 1993; 150: 31-8.

[125] Wykes M, Pombo A, Jenkins C, MacPherson G. Dendritic cells interact directly with naive $\mathrm{B}$ lymphocytes to transfer antigen and initiate class switching in a primary T-dependent response. J Immunol 1998; 161: 1313-9. 
[126] MacPherson G, Kushnir N, Wykes M. Dendritic cells, B cells and the regulation of antibody synthesis. Immunol Rev 1999; 172: 325-34.

[127] Huang N-N, Han S-B, Hwang I-Y, Kehrl J. B cells productively engage soluble antigen-pulsed dendritic cells: visualization of livecell dynamics of B cell-dendritic cell interactions. J Immunol 2005; 175: 7125-34.

[128] Qi H, Egen J, Huang A, Germain R. Extrafollicular activation of lymph node B cells by antigen-bearing dendritic cells. Science 2006; 312: $1672-6$.

[129] Ebner S, Hofer S, Anh Nguyen V, et al. A novel role for IL-3: human monocytes cultured in the presence of IL-3 and IL-4 differentiate into dendritic cells that produce less IL-12 and shift Th cell responses toward a Th2 cytokine pattern. J Immunol 2002; 168: 6199-207.

[130] Dzionek A, Fuchs A, Schmidt P, et al. BDCA-2, BDCA-3, and BDCA-4: three markers for distinct subsets of dendritic cells in human peripheral blood. J Immunol 2000; 165: 6037-46.

[131] Summers KL, Hock BD, McKenzie JL, Hart DNJ. Phenotypic characterization of five dendritic cell subsets in human tonsils. Am J Pathol 2001; 159: 285-95.

[132] Penna G, Vulcano M, Roncari A, Facchetti F, Sozzani S, Adorini L. Cutting edge: differential chemokine production by myeloid and plasmacytoid dendritic cells. J Immunol 2002; 169: 6673-6.

[133] Iyoda T, Shimoyama S, Liu K, et al. The CD8+ dendritic cell subset selectively endocytoses dying cells in culture and in vivo. J Exp Med 2002; 195: 1289-302.

[134] Steinman R, Hawiger D, Nussenzweig M. Tolerogenic dendritic cells. Ann Rev Immunol 2003; 21: 685-711.

[135] Blachere NE, Darnell RB, Albert ML. Apoptotic cells deliver processed antigen to dendritic cells for cross-presentation. PLoS Biol 2005; 3: e185.

[136] Siegal F, Kadowaki N, Shodell M, et al. The nature of the principal type 1 interferon-producing cells in human blood. Science 1999; 284: 1835-7.

[137] McKenna K, Beignon A-S, Bhardwaj A. Plasmacytoid dendritic cells: linking innate and adaptive immunity. J Virol 2005; 79: 17-27.

[138] Lozzi SP, Machado CR, Gerken SE, Mota-Santos TA. Involvement of regional lymph nodes after penetration of schistosoma mansoni cercariae in naive and infected mice. Mem Inst Oswaldo Cruz 1996; 91: 491-8.

[139] Blimczok D, Rothkotter H. Lymphocyte migration studies. Vet Res 2006; 37: 325-8.

[140] MacPherson A, Smith K. Mesenteric lymph nodes at the center of immune anatomy. J Exp Med 2006; 203: 497-500.

[141] Webster B, Ekland E, Agle L, Chyou S, Ruggieri R, Lu T. Regulation of lymph node vascular growth by dendritic cells. J Exp Med 2006; 203: 1903-13.

[142] McHeyzer-Williams L, Malherbe L, McHeyzer-Williams M. Checkpoints in memory B-cell evolution. Immunol Rev 2006; 211: 255-68.

[143] Speirs RS, Gallagher MT, Rauchwerger J, Heim LR, Trentin JJ. Lymphoid cell dependence of eosinophil response to antigen. II. location of memory cells and their dependence upon thymic influence. Exp Hematol 1973; 1: 150-8.

[144] Ponzio NM, Speirs RS. Lymphoid cell dependence of eosinophil response to antigen. 3. Comparison of the rate of appearance of two types of memory cells in various lymphoid tissues at different times after priming. J Immunol 1973; 110: 1363-70.

[145] Ponzio NM, Speirs RS. Lymphoid cell dependence of eosinophil response to antigen. V. Evidence for the induction of separate memory cells mediating cellular and humoral responses to tetanus toxoid. Zeithschrift Immunitatsforschung 1974; 146: 405-13.

[146] Ellyard J, Avery D, Phan T, Hare N, Hodgkin P, Tangye S. Antigenselected, immunoglobulin-secreting cells persist in human spleen and bone marrow. Blood 2004; 103: 3805-12.

[147] MacAllan D. B-cell kinetics in humans: rapid turnover of peripheral blood memory cells. Blood 2005; 105: 3633-40.

[148] McGarry MP, Speirs RS, Jenkins VK, Trentin JJ. Lymphoid cell dependence of eosinophil response to antigen. J Exp Med 1971; 134: $801-14$.

[149] Miller JF. A scientific odyssey: unravelling the secrets of the thymus. Med J Australia 2005; 183: 582-4

[150] Cohn DA, Athanassiades TJ, Speirs RS. Inflammatory cell responses to antigen in thymus deprived mice: reduced eosinophils and mononuclear cells. J Reticuloendothel Soc 1974; 15: 199-212.

[151] Padgett D, Glaser R. How stress influences the immune response. Trends Immunol 2003; 24: 444-8.
[152] Speirs R. A method of assaying adrenal cortical hormones based on a decrease in the circulating eosinophil cells of adrenalectomized mice. Endocrinology 1951; 48: 316-26.

[153] Speirs R. Eosinopenic response of adrenalectomized mice to a cutaneous application of cortisone. Science 1951; 113: 621-3.

[154] Speirs R, Wenck U. Effect of cortisone on the cellular response during allergic inflammation. Acta Hematol 1957; 17: 271-9.

[155] Wenck U, Speirs R. The effect of cortisone on blood leucocytes and peritoneal fluid cells of mice. Acta Hematol 1957; 17: 193-201.

[156] Speirs RS. Effect of $500 \mathrm{r}$ whole body irradiation on the cellular composition of the peritoneal fluid following an intraperitoneal injection of antigen in mice. J Immunol 1956; 77: 437-43.

[157] Speirs RS. Effect of $x$-irradiation on the cellular and humoral responses to antigen. Ann NY Acad Sci 1964; 114: 424-41.

[158] Ponzio NM, Speirs RS. Lymphoid cell dependence of eosinophil response to antigen. IV. Effects of in vitro x-irradiation on adoptive transfer of anamnestic cellular and humoral responses. Proc Soc Exp Biol Med 1974; 145: 1178-80.

[159] Uhr J, Scharff M. Delayed hypersensitivity. V. The effect of xirradiation on the development of delayed hypersensitivity and antibody formation. J Exp Med 1960; 112: 65-76.

[160] Lawrence D, Weigle W. Stimulation of antibody production to the hapten 2,4 dinitrobenzene by affinity labeled murine lymphoid cells: I. the ability of affinity labeled murine lymphoid cells to activate the in vivo immune response. J Exp Med 1974; 139: 943-56.

[161] Basten A, Beeson P. Mechanism of eosinophilia. II. Role of the lymphocyte. J Exp Med 1970; 131: 1288-305.

[162] Medawar P. Review lecture. Immunosuppressive agents, with special reference to antilymphocytic serum. Proc R Soc Lond B Biol Sci 1969; $174: 155-72$

[163] Kerbel RS, Eidinger D. Variable effects of anti-lymphocyte serum on humoral antibody formation: role of thymus dependency of antigen. J Immunol 197; 106: 917-26.

[164] Caulfield M, Shaffer D. Immunoregulation by antigen/antibody complexes. I. Specific immunosuppression induced in vivo with immune complexes formed in antibody excess. J Immunol 1987; 138 : 3680-3.

[165] Heyman B. Regulation of antibody responses via antibodies, complement, and Fc receptors. Ann Rev Immunol 2000; 18: 709-37.

[166] Mosmann TR, Sad S. The expanding universe of T-cell subsets: Th1, Th2 and more. Immunol Today 1996; 17: 138-46.

[167] Mosmann TR, Coffman RL. TH1 and TH2 cells: different patterns of lymphokine secretion lead to different functional properties. Ann Rev Immunol 1989; 7: 145-73.

[168] Speirs RS, Speirs EE, Jansen V. A quantitative approach to the study of inflammatory cells. Proc Soc Exp Biol Med 1961; 106: 248-51.

[169] Athanassiades TJ, Speirs RS. Formation of antigen-induced granulomas containing plasma cells: a light and electron microscopic study. J Reticuloendothel Soc 1968; 5: 485-97.

[170] Cominos D, Strutton G, Busmanis I. Granulomas associated with tetanus toxoid immunization. Am J Dermopathol 1993; 15: 114-7.

[171] Chong H, Brady K, Metze D, Calonje E. Persistent nodules a injection sites (aluminium granuloma)-clinicopathological study of 14 cases with a diverse range of histological reaction patterns. Histopathology 2006; 48: 182-8.

[172] Gray D, Matzinger P. T cell memory is short-lived in the absence of antigen. J Exp Med 1991; 174: 969-74.

[173] Traggiai E, Puzone R, Lanzavecchia A. Antigen dependent and independent mechanisms that sustain serum antibody levels. Vaccine 2003; 21(Suppl 2): 35-7.

[174] Racanelli V, Frassanito M, Leone $\mathrm{P}$, et al. Antibody production and in vitro behavior of $\mathrm{CD} 27$-defined B-cell subsets: persistent hepatitis C virus infection changes the rules. J Virol 2006; 80: 3923-34.

[175] Donaldson SL, Kosco MH, Szakal AK, Tew JG. Localization of antibody-forming cells in draining lymphoid organs during long-term maintenance of the antibody response. J Leuk Biol 1986; 40: 147-57.

[176] Manz RA, Hauser AE, Hiepe F, Radbruch A. Maintenance of serum antibody levels. Ann Rev Immunol 2005; 23: 367-86.

[177] Valadi H, Ekström K, Bossios A, Sjöstrand M, Lee JJ, Lötvall JO Exosome-mediated transfer of mRNAs and microRNAs is a novel mechanism of genetic exchange between cells. Nat Cell Biol 2007; 9 : 654-9.

[178] Dinger M, Mercer T, Mattick J. RNAs as extracellular signaling molecules. J Mol Endocrinol 2008; 40: 151-9.

[179] Belting M, Wittrup A. Nanotubes, exosomes, and nucleic acidbinding peptides provide novel mechanisms of intercellular 
communication in eukaryotic cells: implications in health and disease. J Cell Biol 2008; 183: 1187-91.

[180] Théry C, Boussac M, Véron P. Proteomic analysis of dendritic cellderived exosomes: a secreted subcellular compartment distinct from apoptotic vesicles. J Immunol 2001; 166: 7309-18.

[181] Pisitkun T, Shen R-F, Knepper MA. Identification and proteomic profiling of exosomes in human urine. Proc Natl Acad Sci USA 2004; 101: 13368-73.

[182] Caby M-P, Lankar D, Vincendeau-Scherrer C, Raposo G, Bonnerot C. Exosomal-like vesicles are present in human blood plasma. Int Immunol 2005; 17: 897-87.

[183] Admyre C, Johansson S, Qazi K, et al. Exosomes with immune modulatory features are present in human breast milk. J Immunol 2007; 179: 1696-978.

[184] Li X, Zhang Z, Schluesener H, Xu S. Role of exosomes in immune regulation. J Cell Mol Med 2006; 10: 364-75.

[185] Beauvillain C, Ruiz S, Guiton R, Bout D, Dimier-Poisson I. A vaccine based on exosomes secreted by a dendritic cell line confers protection against $\mathrm{T}$. gondii infection in syngeneic and allogeneic mice. Microbes Infect 2007; 9: 1614-22.

[186] Mattick J. A new paradigm for developmental biology. J Exp Biol 2007; 210: 1526-47.

[187] Raposo G, Nijman H, Stoorvogel W, Liejendekker R, Harding C, Melief C. B lymphocytes secrete antigen-presenting vesicles. J Exp Med 1996; 183: 1161-72.

[188] Zitvogel L, Regnault A, Lozier A, et al. Eradication of established muring tumors using a novel cell-free vaccine: dendritic cell-derived exosomes. Nat Med 1998; 4: 594-600.

[189] Calame K, Lin K, Tunyaplin C. Regulatory mechanisms that determine the development and function of plasma cells. Ann Rev Immunol 2003; 21: 205-30.

[190] Simmons C, Clare S, Ghaem-Maghami M, et al. Central role for B lymphocytes and CD4+ $\mathrm{T}$ cells in immunity to infection by the attaching and effacing pathogen citrobacter rodentium. Infect Immun 2003; 71: 5077-86.

[191] Corcoran LM. Transcriptional control of B cell activation. Curr Top Microbiol Immunol 2005; 290: 105-46.

[192] Kallies A, Hasbold J, Tarlinton D, et al. Plasma cell ontogeny defined by quantitative changes in Blimp-1 expression. J Exp Med 2004; 200 : 967-77.

[193] Afonyushkin T, Veerek B, Moll I, Bläsi U, Kaberdin V. Both RNase $\mathrm{E}$ and RNase III control the stability of sodB mRNA upon translational inhibition by the small regulatory RNA RyhB. Nucleic Acids Res 2005; 33: 1678-89.

[194] Kimata H, Yoshida A, Ishioka C, Mikawa H. Differential effect of vasoactive intestinal peptide, somatostatin, and substance $\mathrm{P}$ on human IgE and IgG subclass production. Cell Immunol 1992; 144: 429-42.

[195] Dubucquoi S, Desreumaux P, Janin A, et al. Interleukin 5 synthesis by eosinophils: association with granules and immunoglobulindependent secretion. J Exp Med 1994; 179: 703-8.

[196] Turner JCA, Mack DH, Davis MM. Blimp-1, a novel zinc fingercontaining protein that can drive the maturation of $\mathrm{B}$ lymphocytes into immunoglobulin-secreting cells. Cell 1994; 77: 297-306.

[197] Lin Y, Wong K-K, Calame K. Repression of c-myc transcription by Blimp-1, an inducer of terminal B cell differentiation. Science 1997; 276: 596-9.

[198] Adachi T, Alam R. The mechanism of IL-5 signal transduction. Am J Physiol 1998; 275: 623-33.

[199] Angelin-Duclos C, Cattoretti G, Ki L, Calame K. Commitment of B lymphocytes to a plasma cell fate is associated with Blimp-1 expression in vivo. J Immunol 2000; 165: 5462-71.

[200] Lin K-I, Tunyaplin C, Calame K. Transcriptional regulatory cascades controlling plasma cell differentiation. Immunol Rev 2003; 194: 1928.

[201] Kallies A, Hawkins ED, Belz GT, et al. Transcriptional repressor Blimp-1 is essential for $\mathrm{T}$ cell homeostasis and self-tolerance. Nat Immunol 2006; 7: 466-74.

[202] Kuritani T, Cooper MD. Human b-cell differentiation. I. analysis of immunoglobulin heavy chain switching using monoclonal antiimmunoglobulin M, G, and A antibodies and pokeweed mitogeninduced plasma cell differentiation. J Exp Med 1982; 155: 839-51.

[203] Chvatchko Y, Kosco-Vilbois MH, Herren S, Lefort J, Bonnefoy JY. Germinal center formation and local immunoglobulin $\mathrm{E}$ (IgE) production in the lung after an airway antigenic challenge. J Exp Med 1996; 184: 2353-60.
[204] Golby S, Spencer J. Where do IgA plasma cells in the gut come from? Gut 2002; 51: 150-1.

[205] Perfetti V, Vignarelli MC, Palladini G, Navazza V, Giachino C, Merlini G. Insights into the regulation of immunoglobulin light chain gene rearrangements via analysis of the kappa light chain locus in lambda myeloma. Immunology 2004; 112: 420-7.

[206] Jung D, Alt FW. Unraveling V(D)J recombination insights into gene regulation. Cell 2004; 116: 299-311.

[207] Pauza M, Rehmann J, LeBien T. Unusual patterns of immunoglobulin gene rearrangement and expression during human $\mathrm{B}$ cell ontogeny: human B cells can simultaneously express cell surface kappa and lambda light chains. J Exp Med 1993; 178: 139-49.

[208] Xu D. Dual surface immunoglobulin light-chain expression in B-cell lymphoproliferative disorders. Arch Pathol Lab Med 2006; 130: 8536.

[209] Yellin MJ, Sippel K, Inghirami G, et al. Activating molecule/CD40$\mathrm{L}$ : potential role in regulating helper effector function. $\mathrm{J}$ Immunol 1994; 152: 598-608.

[210] Alam R, Stafford S, Forsythe P, et al. RANTES is a chemotactic and activating factor for human eosinophils. J Immunol 1993; 150: 34428.

[211] Conti P, Barbacane RC, Feliciani C, Reale M. Expression and secretion of RANTES by human peripheral blood CD4+ cells are dependent on the presence of monocytes. Ann Clin Lab Sci 2001; 31: 75-84.

[212] Walzer T, Marçais A, Saltel F, Bella C, Jurdic P, Marvel J. Immediate RANTES secretion by resting memory CD8 T cells following antigenic stimulation. J Immunol 2003; 170: 1615-9.

[213] Veldhoen S, Laufer SD, Trampe A, Restle T. Cellular delivery of small interfering RNA by a non-covalently attached cell-penetrating peptide: quantitative analysis of uptake and biological effect. Nucleic Acids Res 2006; 34: 6561-73.

[214] Richard JP, Melikov K, Vives E, et al. Cell-penetrating peptides. A reevaluation of the mechanism of cellular uptake. J Biol Chem 2003; 278: 585-90

[215] Holm T, Johansson H, Lundberg P, Pooga M, Lindgren M, Langel U. Protocol to study the uptake of cell-penetrating peptides. Nat Protocol 2006; 1: 1001-5.

[216] Zielinski J, Kilk K, Peritz T, et al. In vivo identification of ribonucleoprotein-RNA interactions. Proc Natl Acad Sci USA 2006; 103: 1557-62.

[217] Maeda T, Kitazoe M, Tada H, et al. Growth inhibition of mammalian cells by eosinophil cationic protein. FEBS J 2002; 269: 307-16.

[218] Valencia-Sanchez M, Liu J, Hannon G, Parker R. Control of translation and mRNA degradation by miRNAs and siRNAs. Genes Dev 2006; 20: 515-24.

[219] Pederson T. RNA interference and mRNA silencing, 2004: how far will they reach? Mol Biol Cell 2004; 15: 407-10.

[220] Bagasra O, Prillman KR. RNA interference: the molecular immune system. J Mol Histol 2004; 35: 545-53.

[221] Monticelli S, Ansel K, Xiao C, et al. MicroRNA profiling of the murine hematopoietic system. Genome Biol 2005; 6: 71.

[222] Pai SI, Lin YY, Macaes B, Meneshian A, Hung CF, Wu TC. Prospects of RNA interference therapy for cancer. Gene Ther 2006; 13: 464-77.

[223] Campbell DH, Garvey JS. The fate of foreign antigen and speculations as to its role in immune mechanisms. Lab Invest 1961; 10: $1126-50$.

[224] Sabesin SM. Antigen-RNA complexes. Science 1966; 153: 659.

[225] Garvey JS, Reilly EB. Studies of antigen-RNA and immunity. Mol Cell Biochem 1979; 24: 45-62.

[226] De Smedt A, Vanderlinden E, Demanet C, De Waele M, Goossens A, Noppen M. Characterisation of pleural inflammation occurring after primary spontaneous pneumothorax. Eur Resp J 2004; 23: 896-900.

[227] Tsuji K, Yamamoto S, Ou W, et al. dsRNA enhances eotaxin-3 production through interleukin-4 receptor upregulation in airway epithelial cells. Eur Resp J 2005; 26: 795-803.

[228] Gan J, Tropea J, Austin B, Court D, Waugh D, Ji X. Structural insight into the mechanism of double-stranded RNA processing by ribonuclease III. Cell 2006; 124: 355-66.

[229] Lamontagne B, Larose S, Boulanger J, Elela SA. The RNase III family: a conserved structure and expanding functions in eukaryotic dsRNA metabolism. Curr Issues Mol Biol 2001; 3: 71-8.

[230] Blaszczyk J, Gan J, Tropea J, Court D, Waugh D, Ji X. Noncatalytic assembly of ribonuclease III with double-stranded RNA. Structure 2004; 12: 457-66. 
[231] Hicks MJ, Yang C, Kotlajich MV, Hertel KJ. Linking splicing to pol II transcription stabilizes pre-mRNAs and influences splicing patterns. PLoS Biol 2006; 4: e147.

[232] Soller M. Pre-messenger RNA processing and its regulation: a genomic perspective. Cell Mol Life Sci 2006; 63: 796-819.

[233] Black SJ, Tokushia T, Herzenberg LA, Herzenberg LA. Memory B cells at successive stages of differentiation: expression of surface IgD and capacity for self renewal. Eur J Immunol 1980; 10: 846-51.

[234] Shi Y, Agematsu K, Ochs H, Sugane K. Functional analysis of human memory $\mathrm{B}$ cell subpopulations: IgD $+\mathrm{CD} 27+\mathrm{B}$ cells are crucial in secondary immune response by producing high affinity IgM. Clin Immunol 2003; 108: 128-37.

[235] Takizawa M, Sugane K, Agematsu K. Role of tonsillar IgD+CD27+ memory $\mathrm{B}$ cells in humoral immunity against pneumococcal infection. Human Immunol 2006; 67: 966-75.

[236] McManus M, Haines B, Dillon C, Sharp P. Small interfering RNAmediated gene silencing in T lymphocytes. J Immunol 2002; 169: 5754-60.

[237] Iwasaki A, Medzhitov R. Toll-like receptor control of the adaptive immune responses. Nat Immunol 2004; 5: 987-95.

[238] Xu D, Liu H, Komai-Koma M. Direct and indirect role of Toll-like receptors in T cell mediated immunity. Cell Mol Immunol 2004; 1: $239-46$.

[239] Akira S. TLR signaling. Curr Top Microbiol Immunol 2006; 311: 1-

[240] Wagner H, Bauer S. All is not toll: new pathways in DNA recognition. J Exp Med 2006; 203: 265-8.

[241] Lanzavecchia A, Bernasconi N, Traggiai E, Ruprecht CR, Corti D, Sallusto F. Understanding and making use of human memory B cells. Immunol Rev 2006; 211: 303-9.

[242] Muzio M, Bosisio D, Polentarutti N, et al. Differential expression and regulation of toll-like receptors (TLR) in human leukocytes: selective expression of TLR3 in dendritic cells. J Immunol 2000; 164: 59986004.

[243] Bell JK, Askins J, Hall PR, Davies DR, Segal DM. The dsRNA binding site of human Toll-like receptor 3. Proc Natl Acad Sci USA 2006; 103: 8792-7.

[244] Heil F, Hemmi H, Hochrein H, et al. Species-specific recognition of single-stranded RNA via toll-like receptor 7 and 8. Sci STKE 2004; 303: $1526-9$

[245] Scheel B, Teufel R, Probst J, et al. Toll-like receptor-dependent activation of several human blood cell types by protamine-condensed mRNA. Eur J Immunol 2005; 35: 1557-66.

[246] Bernasconi N, Onai N, Lanzavecchia A. A role for Toll-like receptors in acquired immunity: up-regulation of TLR9 by BCR triggering in naive B cells and constitutive expression in memory B cells. Blood 2003; 101: 4500-4

[247] Sabroe I, Jones EC, Usher LR, Whyte MK, Dower SK. Toll-like receptors (TLR)2 and TLR4 in human peripheral blood ganulocytes: a critical role for monocytes in leukocyte lipopolysaccharide responses. J Immunol 2002; 168: 4701.
[248] Nagase H, Okugawa S, Ota Y, et al. Expression and function of tolllike receptors in eosinophils: activation by toll-like receptor 7 ligand. J Immunol 2003; 171: 3977-82.

[249] Mansson A, Cardell LO. Activation of espoinophilsvia toll-like receptor (TLR)3, TLR7 and TLR9; link between viral infection and asthma? Eur Resp J 2008; 17: 46-8.

[250] Yang D, Chen Q, Su SB, et al. Eosinophil-derived neurotoxin acts as an alarmin to activate the TLR2-MyD88 signal pathway in dendritic cells and enhances Th2 immune responses. J Exp Med 2008; 205: 91103 .

[251] Zhang Y, Denkers E. Protective role for interleukin-5 during chronic toxoplasma gondii infection. Infect Immun 1999; 67: 4383-92.

[252] Grimaldi JC, Yu NX, Grunig G, et al. Depletion of eosinophils in mice through the use of antibodies specific for $\mathrm{C}-\mathrm{C}$ chemokine receptor 3 (CCR3). J Leuk Biol 1999; 65: 846-53

[253] Ramalingam T, Porte P, Lee J, Rajan TV. Eosinophils, but not eosinophil peroxidase or major basic protein, are important for host protection in experimental brugia pahangi infection. Infect Immun 2005; 73: 8442-3

[254] Herbert D, Lee J, Lee N, Nolan T, Schad G, Abraham D. Role of IL5 in innate and adaptive immunity to larval strongyloides stercoralis in mice. J Immunol 2000; 165: 4544-51.

[255] Ligas J, Kerepesi L, Galioto A, et al. Specificity and mechanism of immunoglobulin $\mathrm{M}$ (IgM)- and IgG-dependent protective immunity to larval strongyloides stercoralis in mice. Infect Immun 2003; 71: 6835-43

[256] King CL, Xianli J, Malhotra I, Liu S, Manhmoud A, Oettgen HC. Mice with a targeted deletion of the IgE gene have increased worm burdens and reduced granulomatous inflammation following primary infection with schistosoma mansoni. J Immunol 1997; 158: 294-300.

[257] Bao S, Beagley KW, Murray AM, et al. Intestinal IgA plasma cells of the B1 lineage are IL-5 dependent. Immunology 1998; 94: 181-8.

[258] Le Goff L, Loke Pn, Ali HF, Taylor DW, Allen JE. Interleukin-5 Is essential for vaccine-mediated immunity but not innate resistance to a filarial parasite. Infect Immun 2000; 68: 2513-7.

[259] Abraham D, Leon O, Schnyder-Candrian S, et al. Immunoglobulin E and eosinophil-dependent protective immunity to larval onchocerca volvulus in mice immunized with irradiated larvae. Infect Immun 2004; 72: 810-7.

[260] Elbashir SM, Harborth J, Lendeckel W, Yalcin A, Weber K, Tuschl T. Duplexes of 21-nucleotide RNAs mediate RNA interference in cultured mammalian cells. Nature 2001; 411: 494-8.

[261] Prasanth KV, Prasanth SG, Xuan Z, et al. Regulating gene expression through RNA nuclear retention. Cell 2005; 123: 249-63.

[262] Nathalie B, Darnell RB. Apoptotic cells deliver processed antigen to dendritic cells for cross-presentation. PLoS Biol 2005; 3: 185.

[263] Takeda K, Kaisho T, Akira A. Toll-like receptors. Ann Rev Immunol 2003; 21:335-76

[264] West A, Koblansky A, Ghosh S. Recognition and signaling by tolllike receptors. Ann Rev Cell Dev Biol 2006; 22: 409-37. 